\title{
Azospirillum brasilense and Solarized Manure on the Production and Phytochemical Quality of Tomato Fruits (Solanum lycopersicum L.)
}

\author{
Alfonso Andrade-Sifuentes ${ }^{1}$, Manuel Fortis-Hernández ${ }^{1}$, Pablo Preciado-Rangel ${ }^{1}$ (D), \\ Jorge Arnaldo Orozco-Vidal ${ }^{1}$, Pablo Yescas-Coronado ${ }^{1}$ and Edgar Omar Rueda-Puente ${ }^{2, *(D)}$ \\ 1 Tecnológico Nacional de México-Campus Instituto Tecnológico de Torreón (TecNm—ITT), Antigua \\ Carretera Torreón-San Pedro km 7.5, Torreón, Coahuila C.P. 27170, Mexico; \\ ing.andrade_85@hotmail.com (A.A.-S.); textrc2010@live.com (M.F.-H.); ppreciador@yahoo.com.mx (P.P.-R.); \\ Joorvi66@hotmail.com (J.A.O.-V.); pyescas@hotmail.com (P.Y.-C.) \\ 2 Departamento de Agricultura y Ganadería, Universidad de Sonora, Bulevard Luis Encinas y Rosales s/n, \\ Colonia Centro, Hermosillo, Sonora C.P. 83000, Mexico \\ * Correspondence: erueda818@gmail.com; Tel.: +52-1-641-327-0764
}

Received: 2 November 2020; Accepted: 10 December 2020; Published: 12 December 2020

\begin{abstract}
Tomato is a vegetable crop with probiotic interest. Currently subject to a global biosecurity emergency due to the epidemic caused by COVID-19, humanity is seeking to maintain its health and become stronger by eating vegetables that have probiotic properties. Considering the request of tomato farmers in the Comarca Lagunera (CL) region, the objective of this work consisted of determining the impact of bioinoculation with Azospirillum brasilense $(\mathrm{Ab})$ and solarized manure (M) on the yield and phytochemical quality of tomato fruits produced in shade mesh. Seeds of the saladette variety TOP 2299 were inoculated with $\mathrm{Ab}$ at $1 \times 10^{8} \mathrm{CFU} \cdot \mathrm{mL}$. Before 46 days after being sowed, seedlings were transplanted in soil enriched with manure solarized at a rate of $0,40,80,120$ and $160 \mathrm{t} \mathrm{ha}^{-1}$; a chemical fertilization (CHF) treatment was also adopted (366-95-635). Emergence, growth, root length, bromatological studies (protein and lipids in plant), yield and organoleptic (Vit C, phenols, flavonoids and lycopene) variables were considered. The results show that biofertilization based on $\mathrm{Ab}+\mathrm{M} 40$ can be an alternative to produce tomato in shade-house conditions in the CL compared with non-inoculated and CHF treatments.
\end{abstract}

Keywords: dry arid zones; sustainability; beneficial microorganisms

\section{Introduction}

Tomato (Solanum lycopersicum L.) is one of the most widely consumed vegetables worldwide, due to the wide versatility of its use (fresh and processed) and due to its high nutraceutical value [1]. Tomato is considered to be a functional food that is rich in fiber, and it contains a wide variety of bioactive compounds that are beneficial for human health [1,2]

The Comarca Lagunera (CL) is formed by two states of Mexico (Coahuila and Durango). It is a recognized area in the production of vegetables, where the tomato is of paramount importance [3]. Problems that this region face are salinity, high temperatures and the low availability of water resources. This last factor is caused by the largest dairy basin in Latin America being in the CL region (720,000 head of dairy cattle), affecting the depletion of aquifers [4]. The continuous extraction of this hydrological resource has led to the availability of water for agricultural irrigation being obtained at depths of $600 \pm 300 \mathrm{~m}$. Currently, this extraction of water is having an effect on the concentration of salts in extracted water, which reaches 8 to $12 \mathrm{~g} \cdot \mathrm{L}$ of water in some areas, while in others within the same CL experience values of 1732 and $3386 \mu \mathrm{S} \cdot \mathrm{cm}$. Likewise, the sodification expressed in the sodium 
absorption index (SAI) is typified as an average with a value of $3.66 \mathrm{meq}$. The water hardness varies from hard to very hard, with averages of 50.47 and $114.00{ }^{\circ} \mathrm{F}$, respectively [5].

The surface directed for tomato in CL was 1199.06 ha in 2019 [6]. Its high productivity depends on conventional agriculture with the usage of high amounts of chemical fertilizers. However, this action has exacerbated the problem of salinization in the region. Currently, agricultural farmers demand sustainable production systems in which the use of chemical fertilization is reduced as much as possible and have dedicated themselves to the use of organic agro-inputs; furthermore, since the LC is a generator of high amounts of manure-a product of dairy cattle-the agricultural sector seeks to use it as a biofertilizer [7].

Derived from the above, there is evidence that the use of organic fertilizers such as solarized bovine manure increases the quality of fruits of vegetables [8,9]. It can provide organic matter and nutrients, improve the physical characteristics and chemicals (structure, moisture retention and fertility) of the soil, increase the microbial population present in the soil and has been shown to reduce some diseases induced by phytopathogenic soil fungi [10,11].

On the other hand, with biofertilizers based on Azospirillum spp., crop yields are increased because they stimulate root growth and, therefore, increase the absorption of nutrients from the soil and thus contribute to less nitrogen loss [12,13], in addition to the increase in the content of phenols and flavonoids in the fruits because they affect the metabolism of sugar and the concentration of vitamins C and B9 [14].

Studies related to inoculation with manure in tomato crop under the conditions of a shade-house in the $\mathrm{CL}$ are lacking. Based on the above, the objective of this work consisted of determining the impact of bioinoculation with Azospirillum brasilense and solarized manure on the yield and phytochemical quality of tomato fruits produced in a shade mesh under the conditions of the Comarca Lagunera Region, Mexico.

\section{Materials and Methods}

The study was carried out in the agricultural area of La Ganadera-VIGO S.A. de C.V., during the spring-summer agricultural cycle in a shade-house, where the characteristics of the support-structure consisted of $2 \mathrm{~mm}$ gauge galvanized steel with $1.25^{\prime \prime}$ and 1.5" square profiles and anti-insect mesh (crystal color) with $25 \times 25$ threads inch of polyethylene treated against ultra-violet rays, caliber 720 , with diffused light and 30\% shade. The location of the experimental site is located $21 \mathrm{~km}$ away from the Torreón-San Pedro highway, Coahuila, Mexico at parallel $25^{\circ} 43^{\prime} 30^{\prime \prime} \mathrm{N}-103^{\circ} 19^{\prime} 19^{\prime \prime} \mathrm{W}$.

\subsection{Microbiological Material}

The microbiological material studied was the genus Azospirillum brasilense (Ab) (DSM 1843, Leibniz-Institut DMSZ, Braunschweig, Germany). A selective culture medium NFb with Congo red [15] and malic acid as the main carbon source was reactivated using the culture medium. Incubation conditions were continuous stirring $(120 \mathrm{rpm})$ and a temperature of $30{ }^{\circ} \mathrm{C}$ [16]. Between 14 and $16 \mathrm{~h}$ (logarithmic phase), the concentration of the culture was determined according to the following procedure: $1 \mathrm{~mL}$ of the Ba culture was poured into a cell to be measured with a spectrophotometer (master spectrum FISHER SCIENTIFIC 415), taking the reading of absorbance at a wavelength of $540 \mathrm{~nm}$ against a liquid $\mathrm{NFb}$ with Congo red and a malic acid medium control without bacteria. The bacterial suspension was diluted to an absorbance of 1.00 unit, and then a concentration of $\mathrm{Ab}$ at $1 \times 10^{8} \mathrm{CFU} \cdot \mathrm{mL}$ was prepared for the treatments (Table 1 ). 
Table 1. Treatments established with Azospirillum brasilense $(\mathrm{Ab})$ as a plant growth-promoting bacterium (PGPB) and doses of solarized manure on tomato plants under shadow house conditions.

\begin{tabular}{cc}
\hline Treatments & Description \\
\hline $\mathrm{T} 1=\mathrm{Ab}$ & Azospirillum brasilense \\
$\mathrm{T} 2=\mathrm{Control}$ & Control without Azospirillum brasilense \\
$\mathrm{T} 3=\mathrm{Ab}+\mathrm{M} 40$ & Azospirillum brasilense + Solarized manure $\left(40 \mathrm{tha}^{-1}\right)$ \\
$\mathrm{T} 4=\mathrm{M} 40$ & Solarized manure $\left(40 \mathrm{tha}^{-1}\right)$ \\
$\mathrm{T} 5=\mathrm{Ab}+\mathrm{M} 80$ & Azospirillum brasilense + Solarized manure $\left(80 \mathrm{tha}^{-1}\right)$ \\
$\mathrm{T} 6=\mathrm{M} 80$ & Solarized manure $\left(80 \mathrm{t} \mathrm{ha}^{-1}\right)$ \\
$\mathrm{T} 7=\mathrm{Ab}+\mathrm{M} 120$ & Azospirillum brasilense + Solarized manure $\left(120 \mathrm{tha}^{-1}\right)$ \\
$\mathrm{T} 8=\mathrm{M} 120$ & Solarized manure $\left(120 \mathrm{tha}^{-1}\right)$ \\
$\mathrm{T} 9=\mathrm{Ab}+\mathrm{M} 160$ & Azospirillum brasilense + Solarized manure $\left(160 \mathrm{tha}^{-1}\right) \mathrm{con}$ \\
$\mathrm{T} 10=\mathrm{M} 160$ & Solarized manure $\left(160 \mathrm{tha}^{-1}\right)$ \\
$\mathrm{T} 11=\mathrm{Ab}+\mathrm{CHF}$ & Azospirillum brasilense + Chemical fertilization \\
$\mathrm{T} 12=\mathrm{CHF}$ & Chemical fertilization \\
\hline
\end{tabular}

\subsection{Manure Solarization}

The solarization of the manure was carried out by collecting it from the weather of a stable in the raw stage (12 days after being evacuated by dairy cattle-Holstein breed-in a state of high production in initial lactation, where the cattle are fed with a food formula rich in protein which is made up of $1.8 \mathrm{~kg}$ of broken corn, $0.9 \mathrm{~kg}$ of wheat bran, $0.5 \mathrm{~kg}$ of soybeans and $1.3 \mathrm{~kg}$ of minerals $\left(\mathrm{Mg}^{++}\right.$and K salts)). Once the manure was collected, it was processed by making mounds that were $5 \mathrm{~m}$ long by $1 \mathrm{~m}$ wide with a height of $0.80 \mathrm{~m}$ and applying $55 \%$ humidity, which was controlled with a Spectrum brand TDR-150 humidity meter; the water used to moisten the manure was running fresh water with a $\mathrm{pH}$ of 7 and EC of $2.5 \mathrm{dS} \mathrm{m}$. Subsequently, the mounds were covered with 30 micron-thick transparent plastic (Plastic Poly Sheeting) without albedo for 90 days, reaching temperatures up to $60 \pm 3^{\circ} \mathrm{C}$. At the end of the 90 day period, the manure was chemically analyzed; results showed a $\mathrm{pH}$ of 7.79 , an ECof $6.8 \mathrm{dS} \cdot \mathrm{m}^{-1}, 5.35 \%$ of organic matter, a total nitrogen of $0.86 \%$ and $0.084 \mathrm{mg} \cdot \mathrm{kg}^{-1} \mathrm{of} \mathrm{NH}_{4}$.

It is worth mentioning that solarized manure has the capacity that, when covered by high albedo plastics, the energy radiated by the sun generates temperatures between 64 and $74{ }^{\circ} \mathrm{C}$, causing pathogenic organisms such as fungi, bacteria, nematodes, weeds and insects to be killed and eliminated [17]. The manure was applied to the experimental site 30 days before sowing according to the treatments indicated in Table 1 , at a rate of $0,40,80,120$ and $160 \mathrm{tha}^{-1}$, which was incorporated at a $30 \mathrm{~cm}$ depth of the soil in order to homogenize it throughout the study area using a tractor with Yanmar Compact Tractor characteristics.

\subsection{Chemical fertilization}

Treatments based on chemical fertilization consisted of applying a 366\%-95\%-635\% $\left(\mathrm{N}-\mathrm{P}_{2} \mathrm{O}_{5}-\mathrm{K}_{2} \mathrm{O}\right)$ formula and considering the nutritional condition of the soil. The fertilizers of urea $\left(\mathrm{CO}\left(\mathrm{NH}_{2}\right)_{2}\right.$ : $46 \%-00 \%-00 \%$ ) [18], mono ammonium phosphate (MAP; $11 \%-52 \%-00 \%)$ and NK $(12 \%-00 \%-46 \%)$ were used. Nitrogen application was divided into three equal parts (five days before transplanting, flowering and fruiting) and applied to one side of the plants. The phosphorus-based fertilizer (MAP) was administered five days before the transplant.

\subsection{Inoculation of Tomato Seeds with Azospirillum brasilense ( $A b$ )}

In the present study, the variety TOP 2299 (Ahern Seeds ${ }^{\circledR}$ ), type saladess, was evaluated. It is characterized by being a vigorous plant that is strong bearing and has thick stems, medium internodes and intermediate-late production cycles. The plant experiences good development at high temperatures in spring-summer cycles. Fruits of large sizes, with an average of 160 to $200 \mathrm{~g}$, maintain their size throughout the production cycle. In this phase, seeds were treated by means of a sterile distilled water wash to eliminate excess dyes and chemical products. Seeds were immersed in $70 \%$ alcohol for $10 \mathrm{~s}$ and then washed three times with sterile distilled water. Next, another disinfection 
with $2 \%$ sodium hypochlorite was carried out for $2 \mathrm{~min}$, followed by washing with sterile distilled water [19]. It should be noted that, according to Maeso et al. [20], this second phase of disinfection had the purpose of treating the seed against seed coat pathogens, mainly against the phytopathogenic bacteria Clavibacter michiganensis.

Once the tomato seed was disinfected and freed from chemical excesses, the inoculation of the seed with $\mathrm{Ab}$ was considered. In this sense, it is worthy of note that, in recent years, the use of fertilizers based on plant growth-promoting microorganisms called rhizobacteria, biostimulants, biofertilizers or inoculants has increased. Although there are many identified microorganisms that are used in this type of fertilizer, the most common belong to Azospirillum; the response to inoculants based on A. brasilense has frequently been successful, since significant increases greater than $30 \%$ have been reported in the production of grain and the dry matter of crops such as corn, beans (Phaseolus vulgaris L.), wheat (Triticum aestioum L.), chickpea (Cicer arietinum L.), grasses (Setaria italica), citrus (Citrus spp.) and broad bean (Vicia faba L.) [12,13]. This inoculation in sorghum, corn and other grasses with Azospirillum is beneficial since it can provide $30 \%-50 \%$ of the $\mathrm{N}$ requirements; it also promotes root growth, which translates into a greater absorption of water and nutrients. Notwithstanding the above, there is a consensus that biological nitrogen fixation in cereals has a low agronomic impact and that the use of bacteria is promising based on their characteristics as plant growth promoters, which includes hormonal aspects [12-14].

Tomato seed inoculation with Ab consisted of immersing $1 \mathrm{~g}$ of tomato seed (360 seeds'g \pm 5 ) in a liquid medium based on Azospirillum brasilense with $1 \times 10^{8} \mathrm{CFU} \cdot \mathrm{mL}$ for $1 \mathrm{~min}$ for each treatment; subsequently, each sample of each treatment (seed $+\mathrm{Ab}$ ) (Table 1) was added to a $50 \mathrm{~mL}$ Kitazato flask and individually subjected to a vacuum at $600 \mathrm{~mm} \mathrm{Hg}$ for $5 \mathrm{~min}$ [19]. Then, seeds were placed in growth chambers containing fine sand and seed and covered with a fine cap of peat-moss (Sunshine, Sun I Cry Horticulture MA, USA) at $25 \pm 3{ }^{\circ} \mathrm{C}$ in dark conditions for $24 \mathrm{~h}$ at an H.r. of 45 . Once seeds emerged, they were placed under greenhouse conditions ( $36^{\circ} \mathrm{C}$, an H.r. of $40 \%$ and 3000 luxe) for 45 days. Before transplanting, seedlings were inoculated at 14 and 26 days after sowing (das), immersing the root system in a bacterial base solution of Azospirillum brasilense with $1 \times 10^{8} \mathrm{CFU} \cdot \mathrm{mL}$ for $10^{\prime \prime}$. Later, seedlings 46 days after sowing were selected and transplanted to a field in macrobasins $17 \mathrm{~m}$ long and $1.5 \mathrm{~m}$ wide into the shadow house, with a five plant $\mathrm{m}$ lineal in beds of soil of $1 \mathrm{~m}$ wide and a distance between beds of $1.90 \mathrm{~m}$; in each bed was $50 \mathrm{~cm}$ between rows from each treatment. A $1 \mathrm{~cm}$ wide plastic structure based on hard polyurethane was buried to prevent microbial migration from one treatment to another. Physical and chemical soil analyses were carried out in order to determine the conditions in which the soil was found to be a franco sandy texture, with a $\mathrm{pH}$ of $7.5, \mathrm{EC}$ of $1.5 \mathrm{dS} \cdot \mathrm{m}^{-1}, 1.4 \%$ of organic matter (OM), $10.50 \mathrm{mg} \cdot \mathrm{kg}^{-1}$ of total nitrogen, $10.50 \mathrm{ppm}$ of $\mathrm{NO}_{3}$ and $15.32 \mathrm{mg} \cdot \mathrm{kg}^{-1} \mathrm{of} \mathrm{NH}_{4}$. During the development of plants, the corresponding treatments with plant growth-promoting bacteria $\mathrm{Ab}$ under study were inoculated in the form of beads (spheres) of alginate at different vegetative stages. The production of beads of alginate was developed [21] with a cellular density of $1 \times 10^{8} \mathrm{UFC}^{\cdot} \mathrm{mL}^{-1}$. The bead inoculation program was applied during the vegetative development of tomato, starting in pre-flowering and flowering stages, which means 60 and 90 days after germination, respectively. Inoculation was accomplished by placing $1 \mathrm{~g}$ of beads with the bacterium within the soil sub-surface, as near to the root system of each plant as possible, in every treatment under study. The conditions $\left(\mathrm{T}{ }^{\circ} \mathrm{C}\right.$, H.r., photsynthetically active radiation (Rfa: me $\mathrm{M}^{-2} \mathrm{~s}^{-1}$ ) and annual mean insolation (Ima $h$ )) in the shadow house are shown in Table 2. 
Table 2. Environmental conditions $\left(\mathrm{T}^{\circ} \mathrm{C}, \mathrm{Hr}\right.$, photosynthetically active radiation (Rfa: $\mathrm{me} \cdot \mathrm{m}^{-2} \mathrm{~s}^{-1}$ ) and average annual insolation (Ima h.day)) present in the different phenological stages of tomato production (saladette variedad TOP 2299) treated by the effect of Azospirillum brasilense (Ab) as a PGPB and manure on the shadow house conditions.

\begin{tabular}{|c|c|c|c|c|}
\hline Stage Phenologic & $\mathbf{T}^{\circ} \mathrm{C}$ & $\begin{array}{l}\text { H.r. } \\
(\%)\end{array}$ & $\begin{array}{c}\mathrm{Rfa} \\
\left(\mathrm{me} \cdot \mathrm{m}^{-2} \mathrm{~s}^{-1}\right)\end{array}$ & $\underset{h}{\operatorname{Ima}}$ \\
\hline Seedling/transplanting (June) & $38 \pm 2{ }^{\circ} \mathrm{C}$ & $<39 \% \mathrm{HR}$ & 550.33 & 13.20 \\
\hline Preflowering (July) & $38 \pm 3{ }^{\circ} \mathrm{C}$ & $<42 \% \mathrm{HR}$ & 555.22 & 13.30 \\
\hline Flowering and fructification (August-September) & $35 \pm 3{ }^{\circ} \mathrm{C}$ & $<50 \% \mathrm{HR}$ & 510.32 & 11.50 \\
\hline Harvest (November) & $30 \pm 4^{\circ} \mathrm{C}$ & $<46 \% \mathrm{HR}$ & 477.43 & 10.40 \\
\hline
\end{tabular}

Rfa: photosynthetically active radiation and Ima: average annual sunshine.days. Rfa and Ima: data from the shadow house. $\mathrm{T}^{\circ} \mathrm{C}$ and H.r.: data for the shadow house.

\subsection{Crop Management}

In order to determine the status of the soil microbiology, we applied a widely used technique for the detection of nematodes [22] and fungi [23]. For this purpose, we collected soil samples from the experimental micro-parcels [23]. The results showed a low population of nematodes, corresponding to the Dorylaimida order (with seven specimens $100 \mathrm{~g}^{-1}$ of soil). Fungal microorganisms were found, including Fusarium spp., Alternaria spp., Rhizoctonia spp. and Aspergillus spp. To avoid the presence of weeds, cleanings were carried out using rakes and hoes, avoiding damaging the root system and aerial part of the plant. Plants were pruned at 60 days and guided to two stems, tutored with black six-gauge polypropylene agricultural raffia. Pollination was carried out by means of bumblebees (Bombus impatiens), placing a hive every $30 \mathrm{~m}^{2}$ with 100 individuals each hive during the entire flowering process until harvest (75 to 180 days). It should be noted that the bees were placed 10 days before flowering to allow the recognition of bumblebees in the production area. In the case of insect pests and fungal and bacterial diseases, including those of an organic-preventive type such as Beauveria bassiana, garlic and oregano extracts were applied.

\subsection{Irrigation}

Irrigation was supplied to the plants according to the phenological stage of the crop by means of a superficial drip irrigation system monitored with Model SR 24" tensiometers-the IRROMETER ${ }^{\circledR}$. The characteristics of the tape irrigation were as follows: $21 \cdot \mathrm{h}$, caliber 16 with $40 \mathrm{~cm}$ distance between droppers (Brand Rivulis). The quality of the irrigation water used in the study corresponded to the following values: a pH of 6, an EC of $2.5 \mathrm{dS} \cdot \mathrm{m}$ and $0.24 \mathrm{ppm}$ of $\mathrm{NO}_{3}$.

\subsection{Harvest}

The harvest began when the fruits presented a pink color at between $30 \%$ and $60 \%$ of the fruit according to the color classification [24]. This activity was carried out until the formation of the 10th cluster-a period that lasted four months. The fruits of each cluster were collected by disinfecting the hands, gloves and cutting material such as scissors and razors, placing those collected in sterile plastic trays and carrying out the measurement of the variables to be evaluated.

\subsection{Treatments and Experimental Design}

The treatments under study were designed from the combination of inoculation with Azospirillum brailense $(\mathrm{Ab})$, with solarized manure. The study consisted of 12 treatments (Table 1), which consisted of inoculation with Azospirillum brailense (Ab); application of solarized manure in doses of 0, 40, 80, 120 and $160 \mathrm{t} \mathrm{ha}^{-1}$; and a control treatment (chemical fertilization: 366-95-635, $\mathrm{N}-\mathrm{P}_{2} \mathrm{O}_{5}-\mathrm{K}_{2} \mathrm{O}$ ). The structure of the treatments corresponded to a complete factorial of 26 with 14 repetitions, and the distribution design in the shadow house consisted of random blocks. 


\subsection{Variables Evaluated}

\subsubsection{Emergence Rate and Final Percentage}

The emergence rate and percentage were measured and recorded once seedlings emerged from the substrate of chamber germination. The number of emerged seedlings was recorded by readings (evaluations) daily (emergence rate), and finally the percentage of emergence (\%) was measured after the fourth day of the trial. The emergence rate was calculated as follows [24]: $M=n 1 / t 1+n 2 / t 2+\ldots$ $\mathrm{n} 4 / \mathrm{t} 4$, where $\mathrm{n} 1, \mathrm{n} 2 \ldots \mathrm{n} 4$ are the numbers of emerged seedlings at times $\mathrm{t} 1, \mathrm{t} 2 \ldots \mathrm{t} 4$ in days. The data regarding the emergence percentage were analyzed taking into account a transformation [25]. The emergence rate, which is the sum of recorded emerged seedlings per day, was evaluated by counting seedlings that had emerged. This variable was only used in two treatments (T1 = TCAz control with $\mathrm{Ab}$ vs. $\mathrm{T} 2=\mathrm{TSAz}$ control without $\mathrm{Ab})$.

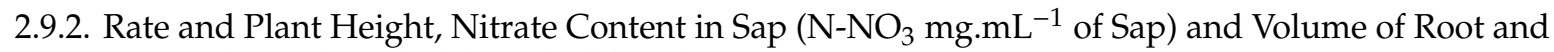
Proteins, Total Lipids and Chlorophyll by Plant

On the other hand, during the first stages (seedling, preflowering and flowering), plants of each treatment were randomly collected in order to measure their plant height on a monthly basis until 100 days after sowing (das); the length of the plants and root systems were measured using a hand scale micrometer (General, 143, General Tools, Manufacturing Co., Inc. New York, NY, USA). In addition to the previous variable, we also evaluated (100 das) the nitrate content in sap ( $\mathrm{N}-\mathrm{NO}_{3} \mathrm{mg} \cdot \mathrm{mL}^{-1}$ of sap), which was obtained by means of the procedure in [26]. In the same phenological stage (100 das), the volume of roots was evaluated; a graduated cylinder was used at a level, and subsequently the root was submerged and the volume quantified with the root inside the cylinder. The data corresponding to this variable are expressed in milliliters $(\mathrm{mL})$ [27]. At the same stage, we collected five plants per treatment; the first leaves from the plant base, jointly with its lateral branches, and the root system were obtained, and we assayed the proteins and lipid content for every plant organ. Proteins were assayed by the micro-Kjeldahl method. The quantification of chlorophylls [28] proceeded by taking $0.1 \mathrm{~g}$ of a sample of leaves from each treatment, and they were homogenized in a mortar using $10 \mathrm{~mL}$ of $80 \%$ acetone as a solvent. The homogenate was filtered, and the filtrate was placed in glass tubes; then, a spectrophotometer was used to perform the absorbance readings of each tube at 663 and $645 \mathrm{~nm}$ wavelengths, using in each case a tube with $10 \mathrm{~mL}$ of $80 \%$ acetone as a blank. Total lipids were assayed [29].

2.9.3. Fruit Size (Polar Diameter and Equatorial Diameter), Soluble Solids, Firmness, Average Weight and Yield $\left(\mathrm{kg} \cdot \mathrm{m}^{2}\right)$

To determine the effect that the treatments induced on the biophysical quality of the fruits, the size of the fruit (polar diameter (DP) and equatorial diameter (DE)) was evaluated using a digital Vernier calibration (Steren Brand); the content of soluble solids (determined in Brix) was measured with a Master-T refractometer (Atago ${ }^{\circledR}$, Tokyo, Japan); the firmness of fruit (FF) was measured with a penetrometer with a $3 \mathrm{~mm}$ plunger (FHT200, Extech Instruments ${ }^{\circledR}$, NJ USA); and the average weight of the fruit was determined using an Ohaus scale (Model $3729^{\circledR}$, D.F., Mexico). The yield $\left(\mathrm{kg} \mathrm{m}^{2}\right)$ was obtained considering all the fruits of commercial size from the first to the 10th bunch per plant. The fruits were harvested when they reached an average weight of between 160 to $200 \mathrm{~g}$. For this, a Brand ADAM analytical balance was used with $450 \mathrm{~g}$ capacity. The results were expressed in kilograms.

\subsubsection{Nutraceutical Quality: Phenolic Content, Flavonoids, Vitamin C and Lycopenes}

For the determination of bioactive phytochemicals, 10 randomly selected tomato fruits from each treatment were analyzed, which were washed with distilled water for $1 \mathrm{~min}$ to eliminate residues. Then, they were manually crushed (in a mortar) and samples of $5 \mathrm{~g}$ of fresh tomato pulp were obtained, which were placed in $10 \mathrm{~mL}$ of methanol in plastic tubes with a screw cap and then placed in a 
rotary shaker (ATR Inc., TX, USA) for $6 \mathrm{~h}$ at $20 \mathrm{rpm}$ and $5{ }^{\circ} \mathrm{C}$. The tubes with the mixture were then centrifuged at $3000 \mathrm{rpm}$ for $10 \mathrm{~min}$, and the supernatant was extracted for analysis. The phenolic and flavonoid content was determined by a modification of the Folin-Ciocalteau method [30]. The content of vitamin C in the fruit was determined by the titration method [31], in which fresh fruit samples of $10 \mathrm{~g}$ were taken, crushed together with $10 \mathrm{~mL}$ of $2 \%$ hydrochloric acid, filtered and made up to $100 \mathrm{~mL}$ with distilled water in an Erlenmeyer flask; then, $10 \mathrm{~mL}$ of the dilute was titrated with 2,6 dichlorophenolindophenol $\left(1 \times 10^{-3} \mathrm{~N}\right)$. The determination of lycopene was then carried out $[32,33]$.

\subsubsection{Quantification of Bacteria}

The quantification of bacteria adhering to the root system of tomato was carried out at the end of the study (harvest stage). Seven plants from each treatment were washed with sterile, distilled water and introduced for $1 \mathrm{~min}$ into Eppendorf tubes with sterile water. Tubes were agitated for $1 \mathrm{~min}$ to detach bacteria from the roots. Three samples of $100 \mu \mathrm{L}$ were taken from the bacterial solution of each tube and sowed by dispersion on $\mathrm{NFb}$ with Congo red [34] and malic acid as a principal carbon source. Incubation conditions were continuous stirring (120 rpm) and a temperature of $30^{\circ} \mathrm{C}$ [35] in Petri dishes, which were incubated for $24 \mathrm{~h}$ at $30^{\circ} \mathrm{C}$ for $\mathrm{CFU}$ measurement.

\subsection{Statistic Analysis}

The data of the response variables to the factors under study, as well as their interactions, were analyzed by means of an analysis of variance of two ways using the statistical software Statistical Analysis System version 9.4 [36], and the Tukey test was used $(p \leq 0.05)$ for the comparison of means.

\section{Results}

3.1. Emergence Rate and Final Percentage, Rate and Plant Height, Volume of Roots, Nitrats Content in Sap and Proteins, Total Lipids and Chlorophyll by Plant

The results according to the proposed methodology show for the emergence variable (the emergence rate, which is the germination energy of different seed treatments, benefited in this case by $\mathrm{Ab}$ ), which consists of recording the "germination rate", that the shorter the number of days needed to achieve a high percentage of the germination capacity, the greater the germination energy of the seed benefited by Ab. The inoculation of seeds with Azospirillum brasilense (Ab) compared with the non-inoculated treatment was more effective $(p \leq 0.05)$ for the response of the emergence of seedlings (Table 3). On the second day of treatment with $\mathrm{Ab}$, a $100 \%$ rate of emergence of seedlings was reached; however, this level was only obtained for the non-inoculated treatment on the fourth day after sowing. This response showed, for the transplanting (46 das (days after sowing), that those seedlings inoculated with $\mathrm{Ab}$ showed a seedling height of $20 \pm 3 \mathrm{~cm}$; for their part, non-inoculated seedlings exhibited up to $15 \mathrm{~cm}$ in height $(12 \pm 3 \mathrm{~cm})$. However, this significant difference between non-inoculated and inoculated seedlings ( 46 das) was equated at the end of the second month (see Table 3 for the monthly height dynamics). According to the variable of plant height per month, in relation to the analysis of variance by factors, it can be seen that there were no significant differences between factors in each of the evaluated months (manure; inoculation and manure * inoculation interaction) with the exception of the fifth month for the interaction factor (Table 3). However, it is important to note regarding manure that M40 stood out in months 2, 3, 5 and 6 with high numerical values, while the least effective manure was M160. Regarding the inoculation factor, the superior treatment was the one inoculated with $\mathrm{Ab}$; however, the $40 \mathrm{t}$ treatment surpassed the inoculated by $22 \%$ (Figure 1). According to the results on the volume of root the variable, the variance analyses did not show a significance in the interactions of $p \leq 0.05$ (Table 3) for separate factors (manure and inoculation). A similar behavior was observed for the M40 treatment, which surpassed the other treatments-in particular, that based on M160, by $272 \%$.

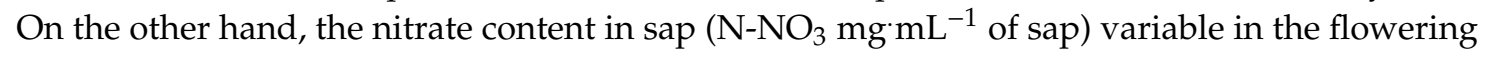
stage did not show significant results (Table 4 ) for factors and for the interaction manure $\times$ inoculation. 
However, the highest values were found for the treatment $\mathrm{Ab}+\mathrm{CHF}(4.59 \pm 0.91)$, followed by $\mathrm{Ab}+$ M40 with $4.59 \pm 0.91 \mathrm{~mL}$ without significant differences $(p \leq 0.05)$. It is important to note that in the variable of sap the $160 \mathrm{t}$ treatment again was the treatment with lowest values (3.93 \pm 0.55$)$. Regarding the inoculation factor, inoculated treatments were higher than non-inoculated treatments.

Regarding the protein present in the root, stem and leaves in the flowering stage, the results showed significance between factors and in the interaction of manure $\times$ inoculation result $(p \leq 0.05)$, with the exception of protein in leaves (Table 4). For the protein in roots, the highest values were for the M40 and M80 manure treatments (at $454.68 \pm 66.80$ and $424.81 \pm 64.35$, respectively) (Figure 2a). For the inoculation factor, treatments with Ab showed the highest values numerically. Similar behavior was detected for stem (Figure 2b), and leaf for the protein variable, where Ab + M40 was the best (1315.80 and $1004.43 \mu \mathrm{g} \cdot \mathrm{g}$, respectively), while the control treatment without Ab and M160 showed the lowest values. Figure $2 \mathrm{c}$ shows the behavior of $\mathrm{Ab}$ and manure interactions (a) for the root protein and (b) on the stem, showing the $\mathrm{Ab}+40 \mathrm{t}$ treatment performed best. On the other hand, in sections $\mathrm{c}, \mathrm{d}$ and e that correspond to lipids in the root, stem and leaf, in Figure 2, the interaction of the mixture between $\mathrm{Ab}$ and manure can be seen to offer better results compared to those that were not inoculated. The $\mathrm{Ab}$ $+\mathrm{M} 40$ and $\mathrm{Ab}+\mathrm{CHF}$ treatments were superior compared to the others. It can also be observed that treatments with high concentrations of manure provided low values in the production of lipids (root, stem and leaf). The highest values of lipids on the root, stem and leaf were for Ab+ M40 (0.613, 0.508 and $2.598 \mu \mathrm{g} \cdot \mathrm{g}$, respectively), outperforming the control treatment by 5108 times (root $=0.12 \mu \mathrm{g} \cdot \mathrm{g}$ ). Concerning the stem and leaf, Ab + M40 outperformed the M160 treatment in terms of the lipids in stem and leaf by 940 times $(0.054 \mu \mathrm{g} \cdot \mathrm{g})$ and 962 times $(0.270 \mu \mathrm{g} \cdot \mathrm{g})$, respectively (Figure 2$)$. In Figure 2f, chlorophyll results are shown, with significant differences obtained only in " $b$ " in the interaction manure $\times$ inoculation treatment $(p \leq 0.05)$. Chlorophyll "a" was among the factors for which there were not significant differences. However, the highest values were for inoculated treatments $(\mathrm{Ab}+\mathrm{M} 40$ : $1.976 \mathrm{mg} \cdot \mathrm{g}$ fresh leaf) compared with M160: 1.500, which was the lowest treatment. In chlorophyll " $\mathrm{b}$ ", inoculated treatments resulted in significant values compared to those that were not inoculated $(\mathrm{Ab}+$ M40: $0.913 \mathrm{mg} \cdot \mathrm{g}$ vs. control $0.736 \mathrm{mg} \cdot \mathrm{g}$ ). 
Table 3. Effect of Azospirillum brasilense ( $\mathrm{Ab}$ ), solarized manure and interaction ( $\mathrm{Ab} \times \mathrm{SM})$ on growth rate and root volume (VR) on tomato plants.

\begin{tabular}{|c|c|c|c|c|c|c|c|c|}
\hline \multirow{2}{*}{ Factor } & \multicolumn{2}{|c|}{ Emergency Seedling } & \multicolumn{5}{|c|}{ Monthly Height Dynamics } & \multirow[b]{2}{*}{ VR } \\
\hline & Day 1 & Day 2 & 2 & 3 & 4 & 5 & 6 & \\
\hline & \multirow{2}{*}{\multicolumn{2}{|c|}{$\%$}} & \multicolumn{5}{|c|}{$\mathrm{m}$} & $\mathrm{mL}$ \\
\hline & & & \multicolumn{6}{|c|}{ solarized manure } \\
\hline 0 & & & $0.71 \pm 0.09 \mathrm{a}$ & $1.40 \pm 0.19 \mathrm{a}$ & $2.00 \pm 0.05 \mathrm{a}$ & $2.43 \pm 0.21 \mathrm{~b}$ & $2.82 \pm 0.07 \mathrm{a}$ & $56.66 \pm 12.5 \mathrm{a}$ \\
\hline 40 & & & $0.98 \pm 0.06 \mathrm{a}$ & $1.72 \pm 0.06 \mathrm{a}$ & $2.27 \pm 0.22 \mathrm{a}$ & $2.99 \pm 0.21 \mathrm{a}$ & $3.38 \pm 0.38 \mathrm{a}$ & $97.50 \pm 40.0 \mathrm{a}$ \\
\hline 80 & & & $0.93 \pm 0.13 \mathrm{a}$ & $1.66 \pm 0.07 \mathrm{a}$ & $2.25 \pm 0.25 \mathrm{a}$ & $2.69 \pm 0.29 \mathrm{a}$ & $2.88 \pm 0.38 \mathrm{a}$ & $71.33 \pm 23.0 \mathrm{a}$ \\
\hline 120 & & & $0.73 \pm 0.09 \mathrm{a}$ & $1.63 \pm 0.04 \mathrm{a}$ & $2.08 \pm 0.03 \mathrm{a}$ & $2.39 \pm 0.15 b$ & $2.61 \pm 0.29 \mathrm{a}$ & $47.66 \pm 40.0 \mathrm{a}$ \\
\hline 160 & & & $0.68 \pm 0.13 \mathrm{a}$ & $1.30 \pm 0.34 \mathrm{a}$ & $1.61 \pm 0.29 \mathrm{a}$ & $1.91 \pm 0.24 \mathrm{c}$ & $2.33 \pm 0.33 a$ & $35.83 \pm 18.5 \mathrm{a}$ \\
\hline \multirow[t]{2}{*}{$\mathrm{CHF}$} & & & $0.87 \pm 0.07 \mathrm{a}$ & $1.68 \pm 0.09 \mathrm{a}$ & $2.05 \pm 0.07 \mathrm{a}$ & $2.75 \pm 0.74 \mathrm{a}$ & $3.20 \pm 0.40 \mathrm{a}$ & $83.83 \pm 15.0 \mathrm{a}$ \\
\hline & & & \multicolumn{6}{|c|}{ Inoculation } \\
\hline $\mathrm{Ab}$ & $80.00 \pm 4 \mathrm{a}$ & $100.00 \pm 0 \mathrm{a}$ & $0.89 \pm 0.18 \mathrm{a}$ & $1.69 \pm 0.10 \mathrm{a}$ & $2.10 \pm 0.36 \mathrm{a}$ & $2.65 \pm 0.53 \mathrm{a}$ & $3.00 \pm 0.50 \mathrm{a}$ & $76.61 \pm 38.5 \mathrm{a}$ \\
\hline \multirow[t]{3}{*}{ Without $\mathrm{Ab}$} & $23.66 \pm 3 b$ & $70.66 \pm 7 b$ & $0.74 \pm 0.19 \mathrm{a}$ & $1.44 \pm 0.42 \mathrm{a}$ & $1.98 \pm 0.66 \mathrm{a}$ & $2.40 \pm 0.69 \mathrm{a}$ & $2.74 \pm 0.53 \mathrm{a}$ & $54.33 \pm 24.5 \mathrm{a}$ \\
\hline & & & \multicolumn{6}{|c|}{$\mathbf{A b} \times \mathbf{S M}$} \\
\hline & & & ns & ns & ns & * & ns & ns \\
\hline
\end{tabular}

\pm Standard deviation; means with equal letters in a column for each factor are not statistically different (Tukey, $p \leq 0.05) ;$ CHF: chemical fertilization; ${ }^{*}$ and ns $=$ significant and not significant according to Tukey $(p \leq 0.05)$.

Table 4. Effect of Azospirillum brasilense $(\mathrm{Ab})$, solarized manure and interaction $(\mathrm{Ab} \times \mathrm{SM})$ on percentage of nitrates $\left(\mathrm{NO}_{3}\right)$, protein and lipids ( $\mu$ g.g dry weight) in the root, stem and leaf and chlorophyll $(\mathrm{a}, \mathrm{b})$ in tomato plants in the flowering stage.

\begin{tabular}{|c|c|c|c|c|c|c|c|c|c|}
\hline \multirow{2}{*}{ Factor } & \multirow[b]{2}{*}{$\mathrm{NO}_{3}$} & \multicolumn{3}{|c|}{ Protein } & \multicolumn{3}{|c|}{ Lipid } & \multicolumn{2}{|c|}{ Chlorophyll } \\
\hline & & Root & Stem & Leaf & Root & Stem & Leaf & $\mathbf{a}$ & $\mathbf{b}$ \\
\hline & $\%$ & \multicolumn{6}{|c|}{$\mu g \cdot g$ Dry Weight } & \multicolumn{2}{|c|}{ mg.g. Fresh Leaf } \\
\hline \multicolumn{10}{|c|}{ Solarized manure } \\
\hline 0 & $4.05 \pm 0.93 \mathrm{a}$ & $362.91 \pm 50.06 \mathrm{a}$ & $947.90 \pm 59.4 \mathrm{a}$ & $766.53 \pm 202 \mathrm{a}$ & $0.355 \pm 0.246 \mathrm{a}$ & $0.317 \pm 0.17 \mathrm{~b}$ & $1.821 \pm 0.79 \mathrm{a}$ & $1.638 \pm 0.145 \mathrm{a}$ & $0.773 \pm 0.055 \mathrm{~b}$ \\
\hline 40 & $4.36 \pm 0.29 a$ & $454.68 \pm 66.80 \mathrm{a}$ & $1119.65 \pm 198 \mathrm{a}$ & $890.48 \pm 118 a$ & $0.538 \pm 0.120 \mathrm{a}$ & $0.496 \pm 0.07 a$ & $2.386 \pm 0.39 a$ & $1.818 \pm 0.165 \mathrm{a}$ & $0.890 \pm 0.040 \mathrm{a}$ \\
\hline 80 & $4.32 \pm 0.27 \mathrm{a}$ & $424.81 \pm 64.35 \mathrm{a}$ & $1120.30 \pm 172 \mathrm{a}$ & $876.67 \pm 174 a$ & $0.526 \pm 0.120 \mathrm{a}$ & $0.483 \pm 0.05 a$ & $2.315 \pm 0.38 \mathrm{a}$ & $1.730 \pm 0.120 \mathrm{a}$ & $0.850 \pm 0.020 \mathrm{a}$ \\
\hline 120 & $4.39 \pm 0.26 \mathrm{a}$ & $420.53 \pm 26.45 a$ & $1025.31 \pm 113 \mathrm{a}$ & $814.50 \pm 103 \mathrm{a}$ & $0.465 \pm 0.100 \mathrm{a}$ & $0.458 \pm 0.04 \mathrm{a}$ & $2.153 \pm 0.19 a$ & $1.676 \pm 0.115 \mathrm{a}$ & $0.841 \pm 0.020 \mathrm{a}$ \\
\hline 160 & $3.93 \pm 0.55 \mathrm{a}$ & $374.40 \pm 63.15 \mathrm{a}$ & $964.93 \pm 47.8 \mathrm{a}$ & $613.53 \pm 250 a$ & $0.311 \pm 0.170 \mathrm{~b}$ & $0.246 \pm 0.21 \mathrm{~b}$ & $1.123 \pm 0.89 \mathrm{~b}$ & $1.621 \pm 0.135 \mathrm{a}$ & $0.793 \pm 0.030 \mathrm{~b}$ \\
\hline FQ & $4.59 \pm 0.91 \mathrm{a}$ & $394.40 \pm 72.90 \mathrm{a}$ & $1099.41 \pm 116 a$ & $913.01 \pm 50 \mathrm{a}$ & $0.595 \pm 0.100 \mathrm{a}$ & $0.479 \pm 0.04 \mathrm{a}$ & $2.473 \pm 0.36 \mathrm{a}$ & $1.698 \pm 0.090 \mathrm{a}$ & $0.835 \pm 0.030 \mathrm{a}$ \\
\hline \multicolumn{10}{|c|}{ Inoculation } \\
\hline $\mathrm{Ab}$ & $4.53 \pm 0.47 \mathrm{a}$ & $461.31 \pm 53.71 \mathrm{a}$ & $1158.43 \pm 155 \mathrm{a}$ & $949.86 \pm 70.7 a$ & $0.568 \pm 0.060 \mathrm{a}$ & $0.478 \pm 0.036 a$ & $2.383 \pm 0.312 a$ & $1.813 \pm 0.164 \mathrm{a}$ & $0.851 \pm 0.051 \mathrm{a}$ \\
\hline Without $\mathrm{Ab}$ & $4.02 \pm 0.35 \mathrm{a}$ & $349.27 \pm 41.63 \mathrm{~b}$ & $934.06 \pm 47.5 \mathrm{~b}$ & $674.71 \pm 250.7 \mathrm{a}$ & $0.362 \pm 0.230 \mathrm{a}$ & $0.348 \pm 0.214 \mathrm{a}$ & $1.707 \pm 0.610 \mathrm{a}$ & $1.580 \pm 0.397 \mathrm{a}$ & $0.809 \pm 0.008 \mathrm{~b}$ \\
\hline
\end{tabular}

ns * * $\quad$ ns $\mathrm{A} \times \mathrm{SM}$

* *

\pm Standard deviation; means with equal letters in a column for each factor are not statistically different (Tukey, $p \leq 0.05)$; CHF: chemical fertilization; $*$ and ns $=$ significant and not significant according to Tukey $(p \leq 0.05)$. 


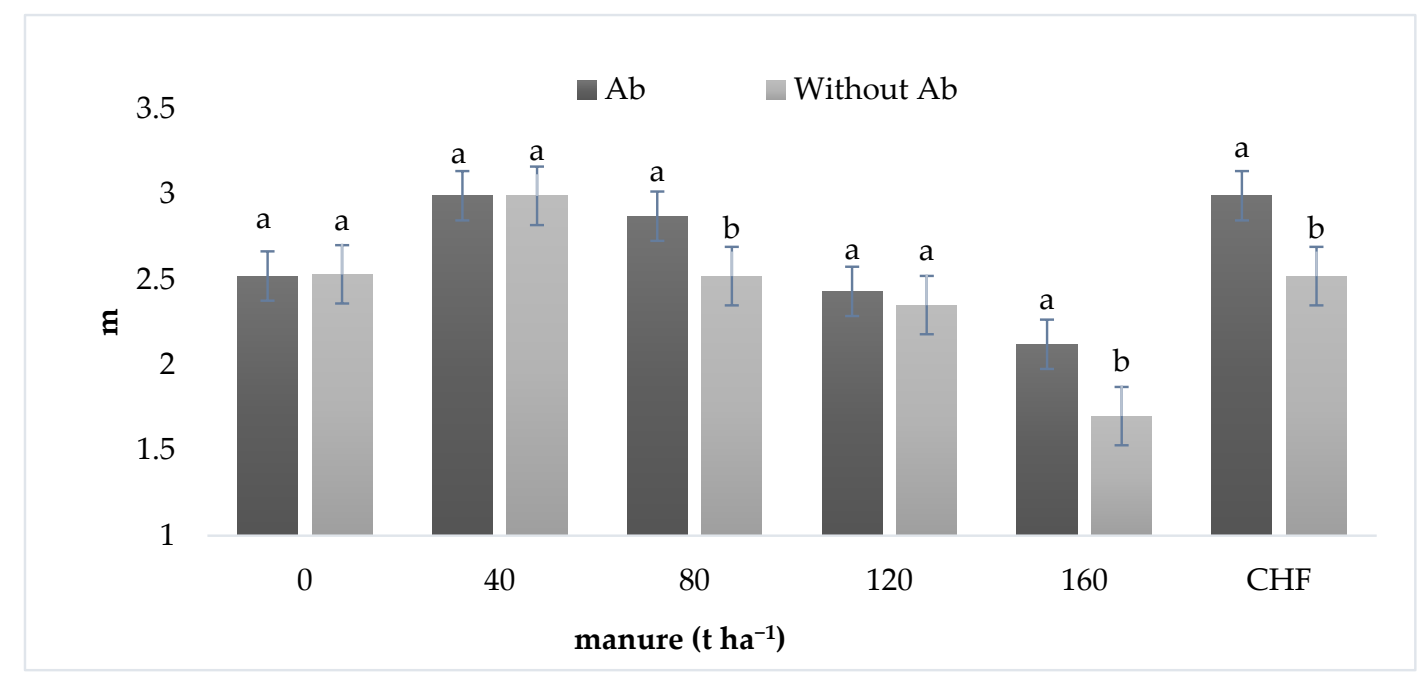

Figure 1. Interaction of Ab-fertilization in plant height at 5 months; $\mathrm{Ab}$ : Azospirillum brasilense; 0, 40, 80, $120,160=$ manure $t^{\cdot h a}{ }^{-1}$; CHF: chemical fertilization. Different literals in the bars indicate significant difference with $p<0.05$.
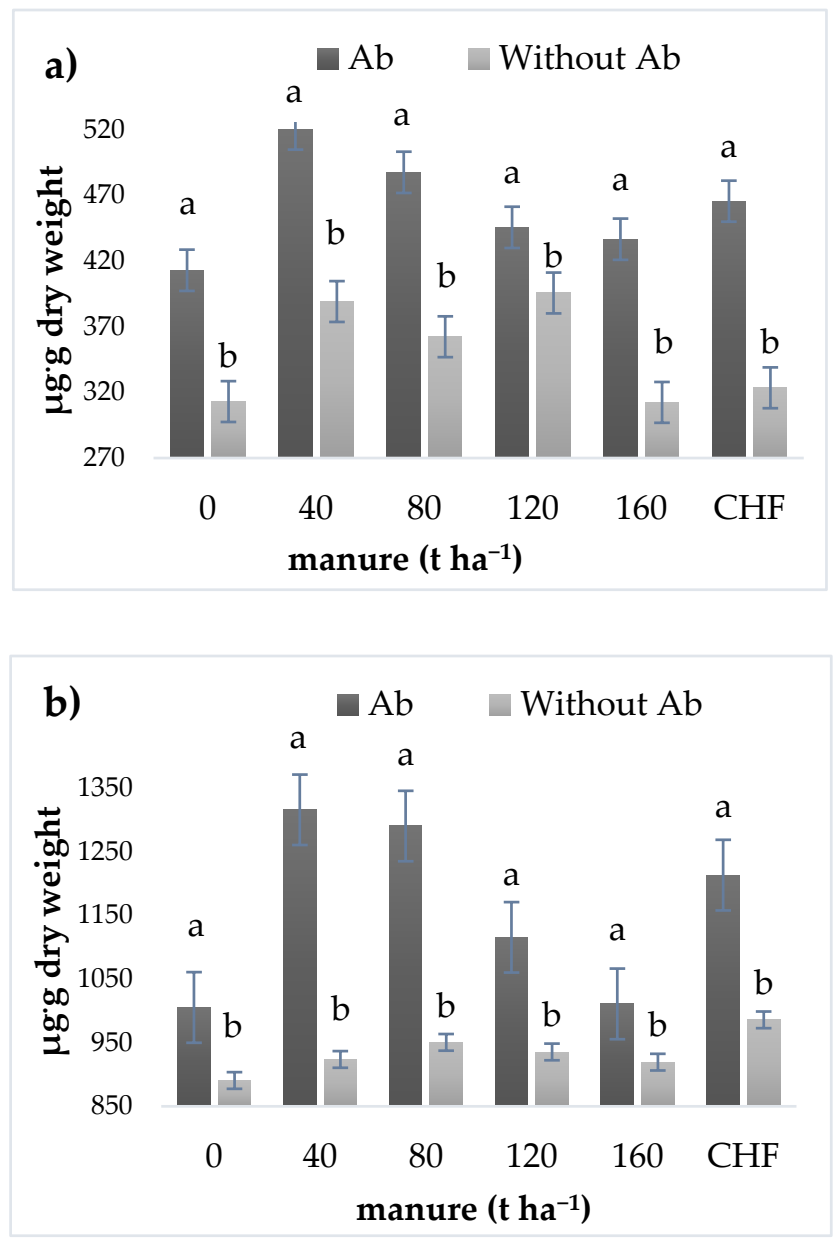

Figure 2. Cont. 

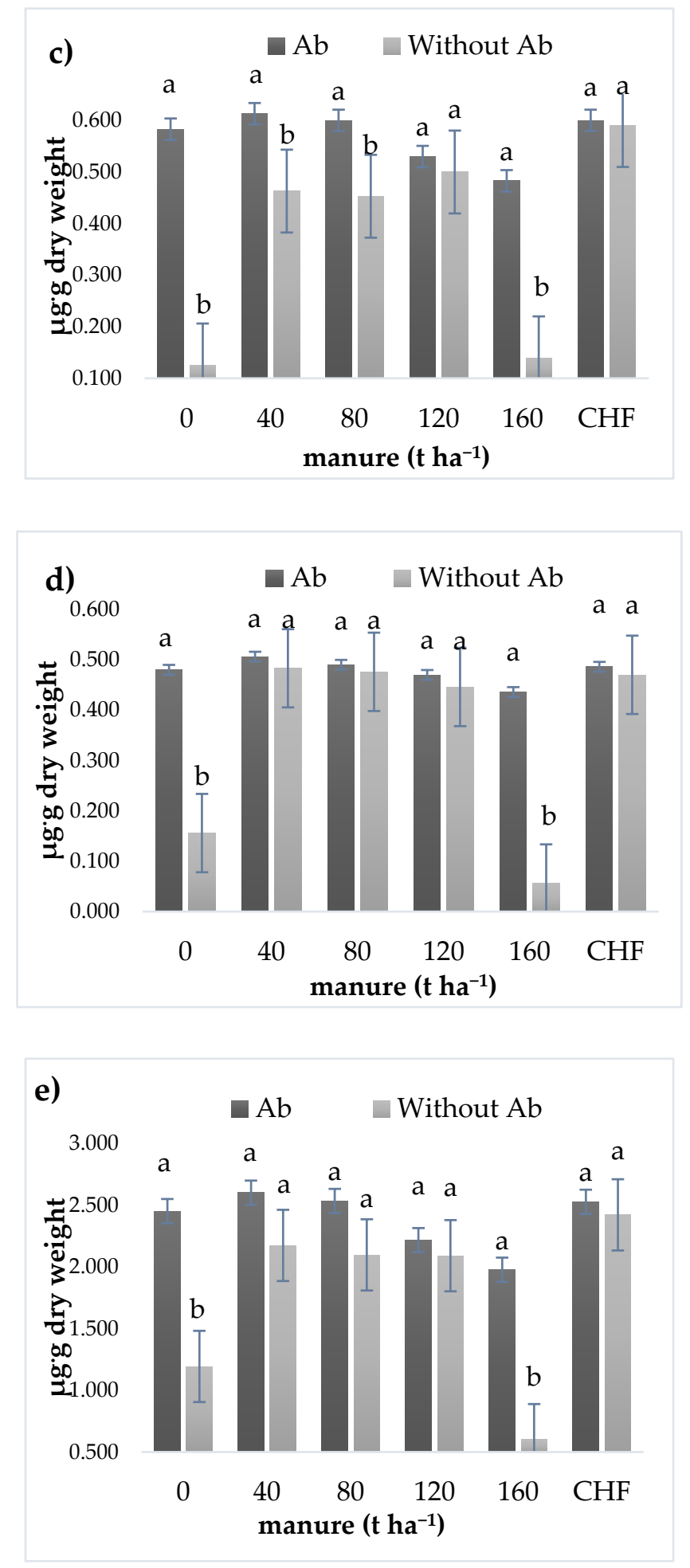

Figure 2. Cont. 


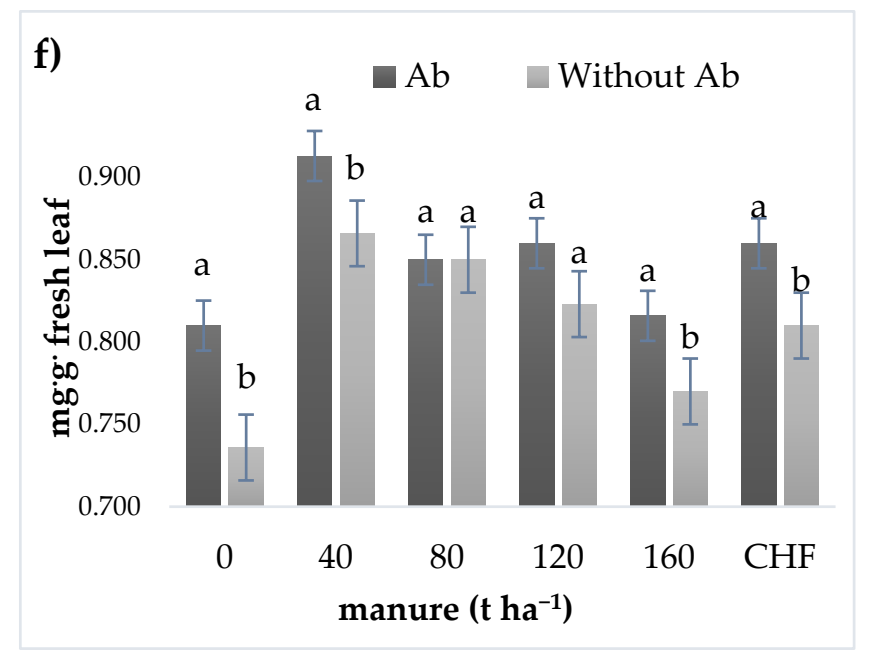

Figure 2. Interaction of $\mathrm{Ab}-$ Fertilization in content of protein in root (a), protein in stem (b), lipid in root (c), lipid in stem (d), lipid in leaf (e) and chlorophyll b (f). Ab: Azospirillum brasilense; 0, 40, 80, $120,160=$ manure $t^{-h}{ }^{-1}$; CHF: chemical fertilization. Different literals in the bars indicate significant difference with $p<0.05$.

3.2. Fruit Size (Polar Diameter and Equatorial Diameter), Soluble Solids, Firmness, Average Weight and Yield $\left(\mathrm{kg} \cdot \mathrm{m}^{2}\right)$

In relation to the polar diameter (DP), equatorial (DE), soluble solids (SS), fruit firmness (FF), fruits per Plant (FP) and yield $\mathrm{kg} \cdot \mathrm{m}^{2}$, results are shown in Table 5. DP, DE and FF did not show significant differences considering simple factors and their interaction. However, the highest values were obtained for inoculated treatments and those with chemical fertilization. According to the analysis of variance for the $\mathrm{Ab}$-manure interaction, a significant difference was found for the SS, FP and $\mathrm{Y}$ variables (Figure 3). The results show that in SS, FP and $Y$ the highest values were for the treatment of $\mathrm{Ab}+160$ in SS, while in FP, the best treatment was $\mathrm{Ab}+\mathrm{CHF}$; the opposite occurred with $\mathrm{Y}$, where $\mathrm{Ab}+\mathrm{M} 40$ treatment was the best (Figure $2 \mathrm{a}-\mathrm{c}$ ). The results showed that treatment inoculated with $\mathrm{Ab}+\mathrm{M} 40$, $\mathrm{Ab}+\mathrm{M} 80$ and $\mathrm{CHF}$ exhibited the highest yield production (13.30, 13.06 and $12.73 \mathrm{~kg} \cdot \mathrm{m}^{2}$, respectively).

\subsection{Nutraceutical Quality: Phenolic Content, Flavonoids, Vitamin C, Lycopene, and Quantification of Bacteria $A b$}

Considering lycopene and phenols in tomato fruits by the effect of $\mathrm{Ab}$ and solarized manure under shade-house conditions, the results reveal that there were significant differences between factors, which is reflected in the significance at the interaction level. Regarding vitamin $C$ and flavonoids, although there was no significance in the interaction, the best treatment in both variables were those with and without $\mathrm{Ab}$ and with M80 manure (Table 6). The highest lycopene and phenol values were represented by Az + M40 and/or Az + M160 (3.56 and $3.56 \mathrm{mg} \cdot 100 \mathrm{~g}$ of tomato, respectively) (Figure 4a,b). 

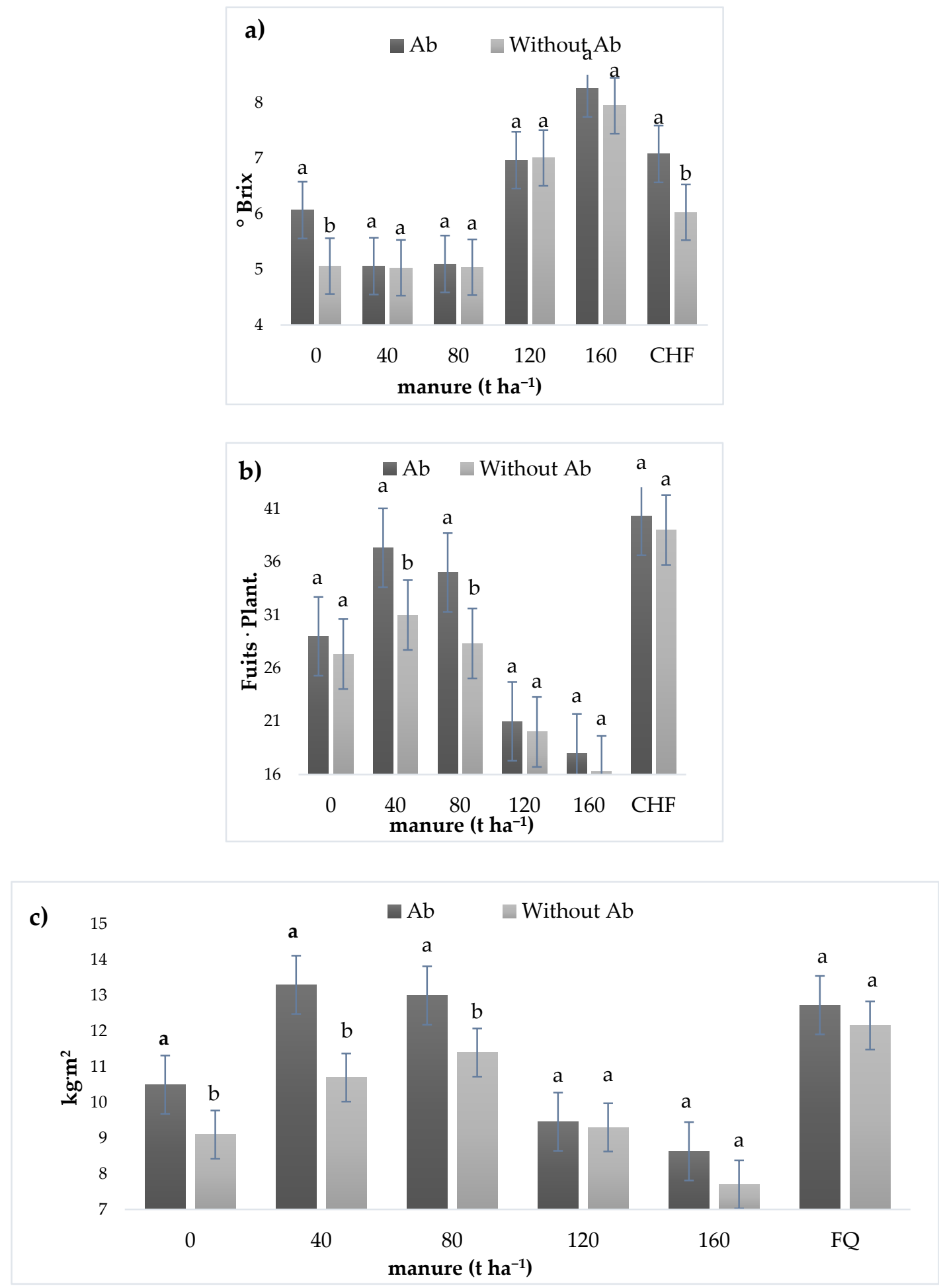

Figure 3. Interaction of Ab-Fertilization in soluble solids (a), fruits/plant (b) and yield per $\mathrm{m}^{2}$ (c). Interaction of $\mathrm{Ab}$-fertilization in terms of plant height at 5 months; $\mathrm{Ab}$ : Azospirillum brasilense; 0, 40, 80, $120,160=$ manure $t^{\cdot h a^{-1}}$; CHF: chemical fertilization. Different literals in the bars indicate significant difference with $p<0.05$. 
Table 5. Effect of Azospirillum brasilense (Ab), solarized manure, and interaction ( $\mathrm{Ab} \times \mathrm{SM}$ ) on polar diameter (DP), equatorial diameter (DE), soluble solids (SS), fruit firmness (FF), fruits per plant (FP) and yield (Y: $\left.\mathrm{kg} \cdot \mathrm{m}^{2}\right)$ on tomato plants.

\begin{tabular}{|c|c|c|c|c|c|c|}
\hline Factor & $\begin{array}{c}\mathrm{DP} \\
\mathrm{mm}\end{array}$ & $\begin{array}{l}\mathrm{DE} \\
\mathrm{mm}\end{array}$ & $\begin{array}{c}\text { SS } \\
\text { Brix }\end{array}$ & $\begin{array}{l}\text { FF } \\
\mathbf{N}\end{array}$ & $\begin{array}{l}\text { FP } \\
\text { No }\end{array}$ & $\begin{array}{c}\mathrm{Y} \\
\mathrm{kg} \cdot \mathrm{m}^{2}\end{array}$ \\
\hline \multicolumn{7}{|c|}{ solarized manure } \\
\hline 0 & $72.95 \pm 2 \mathrm{a}$ & $50.51 \pm 3 a$ & $5.56 \pm 0.66 \mathrm{~d}$ & $10.40 \pm 1.01 \mathrm{a}$ & $28 \pm 1 \mathrm{a}$ & $9.83 \pm 0.77 b$ \\
\hline 40 & $83.90 \pm 3 a$ & $59.08 \pm 7 a$ & $5.05 \pm 0.25 \mathrm{e}$ & $10.32 \pm 1.13 \mathrm{a}$ & $34 \pm 4 \mathrm{a}$ & $12.00 \pm 1.99 \mathrm{a}$ \\
\hline 80 & $78.79 \pm 2 \mathrm{a}$ & $52.43 \pm 4 \mathrm{a}$ & $5.07 \pm 0.22 \mathrm{e}$ & $12.26 \pm 1.03 \mathrm{a}$ & $31 \pm 4 \mathrm{a}$ & $12.20 \pm 1.20 \mathrm{a}$ \\
\hline 120 & $75.10 \pm 3 \mathrm{a}$ & $46.27 \pm 17 \mathrm{a}$ & $6.99 \pm 0.07 b$ & $10.51 \pm 1.03 \mathrm{a}$ & $20 \pm 1 \mathrm{a}$ & $9.38 \pm 1.62 b$ \\
\hline 160 & $70.50 \pm 3 a$ & $51.88 \pm 1 \mathrm{a}$ & $8.10 \pm 0.04 \mathrm{a}$ & $8.80 \pm 1.00 \mathrm{a}$ & $17 \pm 1 b$ & $8.16 \pm 1.74 \mathrm{c}$ \\
\hline $\mathrm{CHF}$ & $83.15 \pm 4 \mathrm{a}$ & $51.65 \pm 6 a$ & $6.55 \pm 0.66 c$ & $11.10 \pm 1.87 \mathrm{a}$ & $39 \pm 1 \mathrm{a}$ & $12.45 \pm 1.45 \mathrm{a}$ \\
\hline \multicolumn{7}{|c|}{ Inoculation } \\
\hline $\mathrm{Ab}$ & $78.17 \pm 8.6 \mathrm{a}$ & $55.04 \pm 1.80 \mathrm{a}$ & $6.42 \pm 1.6 \mathrm{a}$ & $10.57 \pm 1.7 \mathrm{a}$ & $30 \pm 10 \mathrm{a}$ & $11.27 \pm 1.6 \mathrm{a}$ \\
\hline Without $\mathrm{Ab}$ & $76.65 \pm 4.8 \mathrm{a}$ & $48.90 \pm 5.9 \mathrm{a}$ & $6.02 \pm 1.5 b$ & $10.56 \pm 1.7 \mathrm{a}$ & $27 \pm 7 \mathrm{a}$ & $10.07 \pm 1.9 \mathrm{a}$ \\
\hline \multicolumn{7}{|c|}{$\mathrm{Ab} \times \mathrm{SM}$} \\
\hline
\end{tabular}

\pm Standard deviation; means with equal letters in a column for each factor are not statistically different (Tukey, $p \leq 0.05$ ); CHF: chemical fertilization; * and ns $=$ significant and not significant according to Tukey $(p \leq 0.05)$. 
Table 6. Effect of Azospirillum brasilense $(\mathrm{Ab})$, solarized manure, and interaction $(\mathrm{Ab} \times \mathrm{SM})$ on vitamin $\mathrm{C}$, lycopene, phenols and flavonoids in tomato fruits.

\begin{tabular}{|c|c|c|c|c|}
\hline \multirow{2}{*}{ Factor } & Vitamin C & Lycopene & Phenols & Flavonoids \\
\hline & $\operatorname{Mg} 100 g^{-1} \mathrm{PF}$ & $\mathrm{mg} \mathrm{Kg}^{-1} \mathrm{PF}$ & mg AGE/100 g PF & mg QE/100 g PF \\
\hline \multicolumn{5}{|c|}{ Solarized manure } \\
\hline 0 & $8.80 \pm 0.0 \mathrm{~b}$ & $2.73 \pm 0.8 \mathrm{a}$ & $96.150 \pm 4 b$ & $31.36 \pm 9 b$ \\
\hline 40 & $8.80 \pm 0.0 \mathrm{~b}$ & $3.03 \pm 0.8 \mathrm{a}$ & $101.60 \pm 5 b$ & $32.00 \pm 4 b$ \\
\hline 80 & $12.02 \pm 0.5 \mathrm{a}$ & $2.87 \pm 0.8 \mathrm{a}$ & $118.77 \pm 29 \mathrm{a}$ & $45.71 \pm 18 \mathrm{a}$ \\
\hline 120 & $4.40 \pm 0.0 \mathrm{~d}$ & $2.73 \pm 0.8 \mathrm{a}$ & $121.27 \pm 80 \mathrm{a}$ & $50.81 \pm 24 a$ \\
\hline 160 & $4.40 \pm 0.0 \mathrm{~d}$ & $3.03 \pm 0.8 \mathrm{a}$ & $139.60 \pm 24 \mathrm{a}$ & $73.45 \pm 10 \mathrm{a}$ \\
\hline $\mathrm{CHF}$ & $5.28 \pm 0.0 \mathrm{c}$ & $\begin{array}{c}2.10 \pm 0.4 \mathrm{~b} \\
\quad \text { Inoculati }\end{array}$ & $106.84 \pm 6 b$ & $15.43 \pm 7 b$ \\
\hline $\mathrm{Ab}$ & $7.33 \pm 5.0 \mathrm{a}$ & $3.15 \pm 0.4 \mathrm{a}$ & $115.23 \pm 34 \mathrm{a}$ & $35.40 \pm 39 a$ \\
\hline Without $\mathrm{Ab}$ & $7.23 \pm 3.6 b$ & $\begin{array}{c}2.34 \pm 0.1 \mathrm{~b} \\
\mathrm{Ab} \times \mathrm{SN}\end{array}$ & $115.94 \pm 25 \mathrm{a}$ & $47.52 \pm 34 \mathrm{a}$ \\
\hline & $\mathrm{ns}$ & $*$ & * & ns \\
\hline
\end{tabular}

\pm Standard deviation; means with equal letters in a column for each factor are not statistically different (Tukey, $p \leq 0.05)$; CHF: chemical fertilization; ${ }^{*}$ and $\mathrm{ns}=$ significant and not significant according to Tukey $(p \leq 0.05)$.
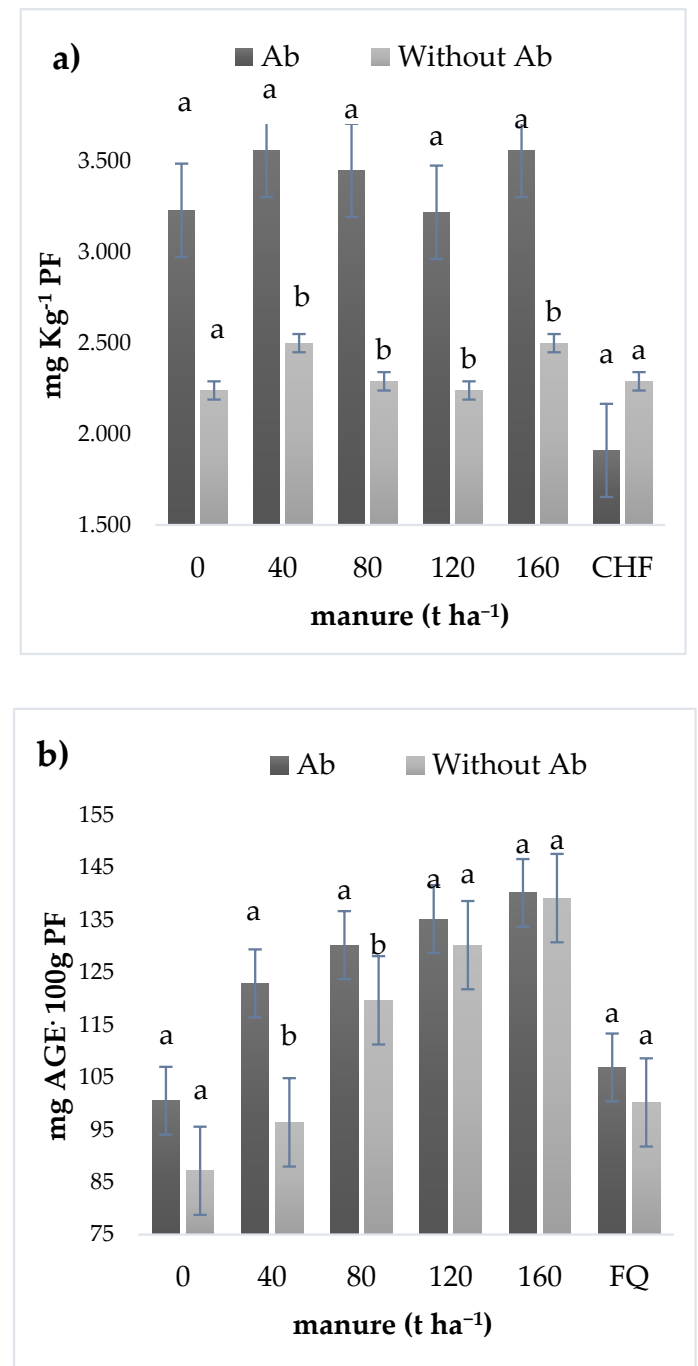

Figure 4. Interaction of Ab-Fertilization in lycopene (a) and phenols (b) in tomato fruit. Ab: Azospirillum brasilense; $0,40,80,120,160=$ manure tha ${ }^{-1}$; CHF: chemical fertilization. Different literals in the bars indicate significant difference with $p<0.05$. 
On the other hand, when counting the number of bacterial cells that adhered to the root of tomato considering different doses of manure, insignificant differences were observed between isolated CFUs. However, it was observed that manure treatments $(\mathrm{Ab}+\mathrm{M} 40, \mathrm{Ab}+\mathrm{M} 60$ and $\mathrm{Ab}+\mathrm{CHF})$ showed higher values $\left(4.10 \pm 1.11 \log _{10} \mathrm{UFC} \cdot \mathrm{mL}\right)$, while $\mathrm{Ab}+\mathrm{M} 80$ and $\mathrm{Ab}+\mathrm{M} 160$ showed values around $3.70 \pm 1.31 \log _{10} \mathrm{UFC} \cdot \mathrm{mL}$.

\section{Discussion}

Food production in recent years has placed significant value on the health of humanity. Currently subject to a global biosafety contingency due to the epidemic caused by COVID-19, humanity is seeking to maintain its health and has come to strengthen itself by feeding on vegetables that have pro-natal properties [37-39]. A particularly important vegetable is the tomato; in this spring-summer season, Mexico has increased the export of tomatoes by an additional 15\% compared with 2019 and monopolized $24.1 \%$ of world trade only in the last eight months of 2020 [40]. With the purpose of emphatically capitalizing on the current global demand for tomato and considering the request of tomato farmers in the Comarca Lagunera region to evaluate Azospirillum brasilense and manure produced by dairy herds, under the methodological conditions that the study proposed, our obtained results confirm those pronounced in [41], together with several others [42-45], which stated that plant growth-promoting bacteria (PGPB) such as Azospirillum have effects on other plants than the originally intended cereals. This study strongly supports the idea that Azospirillum should be considered a non-specific and generally beneficial bacteria. However, since they are proposed as biofertilizers, their effectiveness must be proven in a variety of conventional crop families, and users should avoid limiting it to cereals only [45]; likewise, the positive effects of this bacterium, as observed in the present study, are apparently due to the production of growth-promoting substances, as reported in other studies [46-48]. In our study, as a first approximation regarding the emergence of seedlings, we detected the influence of Azospirllum brasilense (Ab) to be a 300\% increase to the emergence without $\mathrm{Ab}$ on the first day, while $\mathrm{Ab}$ was $30 \%$ more effective on the second day (Table 3) compared with the non-inoculated control. Visually and measurably, during 45 additional days, the seeds inoculated with $\mathrm{Ab}$ were more vigorous in their emergence, large and robust, reaching up to $20 \pm 3 \mathrm{~cm}$ in height at 46 days, while the non-inoculated were only up to $12 \pm 3 \mathrm{~cm}$ high. After 46 days and after transplantation, the seedlings under the effect of $\mathrm{Ab}$, manure and chemical fertilization showed favorable behaviors. In the subsequent months after transplantation, when the plants were subjected to $\mathrm{Ab}$, manure and chemical fertilization (according to the treatments studied and shown in Table 1), those plants that were short on emergence behaved statistically similarly to those for which biofertilization was administered $(\mathrm{Ab}+\mathrm{M})($ Table 3$)$, and it was not until the fifth month at which the height showed a statistical significance between inoculated treatments with those that were not inoculated (Figure 1). It is possible that manure in the soil undergoes a mineral decomposition process in which soil microorganisms participate, breaking their biochemical structures into increasingly simple nitrogen compounds from which plants take nitrogen in the form of $\mathrm{NH}_{4}$ and $\mathrm{NO}_{3}$; this is similar to the process by which, once inside the plant, manure undergoes a reduction process to nitrite $\left(\mathrm{NO}_{2}{ }^{-}\right)$in the cytosol by nitrate reductase using NADH or NADPH. On the other hand, the authors of [49] indicated that inoculation with Azospirillum brasilense caused positive effects on the growth of tomato plants, improving their nutritional status and increasing their yield by $11 \%$ compared to the control plant. In addition, a high population level was obtained in the rhizosphere of the plant. In our study, we detected that the influences of $\mathrm{Ab}+$ manure and $\mathrm{Ab}+\mathrm{CHF}$ were more pronounced than for those treatments that were not inoculated (Table 3). This positive effect was reflected in the volume of the root and, although there was no significance in the interaction between factors, the numerical values were higher in treatments in which the participation of $\mathrm{Ab}+$ manure was present. The values indicate that $\mathrm{Ab}+\mathrm{M}$ reached $115.11 \mathrm{~mL}$ compared to the control without $\mathrm{Ab}$ and/or manure or chemical fertilization, which yielded up to $69.16 \mathrm{~mL}$-a difference of up to $60 \%$ (Table 3). Although no histological sections were made at the root level, we consider that Ab bacteria facilitate the rooting and growth of plants [50]. Azospirillum 
has been found in the intracellular spaces of vascular tissues of stems and roots [51,52] and has been used as an agricultural inoculant due to its ability to stimulate plant growth through nitrogen fixation and the synthesis of plant hormones [53]. This can be attributed to the large number of bacterial $\mathrm{Ab}$ cells at the end of the study, which were shown to adhere to the root walls after the roots had been washed and were subjected to turbulent agitation to release those that had adhered.

Nitrogen $(\mathrm{N})$, in addition to being a specific component of proteins, is present in most of the organic combinations of vegetables [54] Proteins are degraded, causing simpler decomposition products and, finally, part of the nitrogen appears in the form of nitrate. In this way, it can be used by microorganisms and by higher plants to build their protein structures, or it can be reduced, under certain conditions, to its elemental state. This contribution as a whole had repercussions in the present study, meaning that, in the flowering stage, the nitrates were numerically higher in the sap than those treatments inoculated with $\mathrm{Ab}$ and enriched with manure (Table 4). Although nitrates in sap did not reflect a significance with $p<0.05$ in the interaction of factors, an effect was identified from proteins in the root and stem, while for lipids the effect was found in the root, stem and leaves (Figure 2 a-e), identifying that, in chlorophyll " $\mathrm{b}$ ", this interaction was favored for Ab + M40 (Figure 2c). These results can be attributed to the fact that $\mathrm{Ab}$, as a PGPB, tends to make photosynthetic activity more efficient, as well as the chlorophyll content, due to the high levels of $\mathrm{CO}_{2}$ uptake; therefore, there is a greater accumulation of sugars in the fruits [55-57]. The nitrate content in $\mathrm{Ab}+\mathrm{M}(40,80,120$ and 160) and A + CHF plants for all treatments was very high (without significance) with respect to the plants that were not inoculated with the $\mathrm{N}_{2}$-fixing bacteria used in this studio. This apparent inhibition in the uptake or accumulation of nitrates appears to be controversial; however, it should be noted that this refers to $\mathrm{NO}_{3}$ and not total nitrogen. Similar results have been found in studies of corn plants (Zea mays) [56-59]; with levels of fertilizers from $\mathrm{N}_{2}$, the low concentrations of $\mathrm{NO}_{3}$ detected in the sap were directed towards the formation of biomass (Table 5). This behavior can be attributed to the fact that the relatively lower values obtained in sap in the inoculated treatments are reflected in a higher biomass and consequently in more proteins and lipids.

The behavior of PGPBs presents significant benefits for plants, among which the mechanisms of the biosynthesis of plant growth-promoting substances and increased absorption of nutrients-atmospheric nitrogen fixation processes $\left(\mathrm{N}^{2}\right)$ [60] - which directly and indirectly impact the metabolism and physiology of plants, stand out [61,62]. The results in the present study in relation to SS $\left(6.42 \pm 1.6^{\circ}\right.$ Brix) (Table 5) exceed those reported by [63], who found a value of $3.63^{\circ}$ Brix when evaluating the co-inoculation between Pantoea agglomerans, Acinetobacter baumannii and Bacillus megaterium in tomato cultivation. In [64], the authors indicate that the production of phytohormones in the area of root growth stimulates the development of the roots and, therefore, leads to a better absorption of water and nutritive elements; this results in an increase in the absorption of nutrients by the plants when inoculated with PGPB. Studies related to other types of genera that have a positive influence include a work based on the Bacillus sp. strain, which produced the highest contents of SS, lycopene and ascorbic acid in tomato fruits [65], which together with other studies (including the present study) highlights the importance of using this type of plant growth-promoting microorganism.

In addition to the above, studies concerning PGPB show that, in addition to producing phytohormones such as cytokinins and IAA and fixing nitrogen, PGPBs can solubilize phosphate and inhibit the development of phytopathogenic microorganisms, which favors the better development of plants that are still subject to adverse factors such as salinity [66]. Another quality that these types of beneficial microorganisms have is that manure-based fertilizers influence the decrease in the absorption of water and nutrients; this implies an ionic and osmotic stress that affects the metabolism of the plant, but the nutraceutical quality of the fruits is improved [67,68]. Bacillus spp. and Aeromonas spp. were shown in another study [69] to increase the content of ascorbic acid, SS and lycopene under greenhouse conditions-an effect attributed to the fact that PGPB can synthesize phytohormones [70]. The results in the present study for DP, De, SS, FF, FP and Y allow us to suppose that a biofertilization based on $\mathrm{Ab}$ + manure can be an alternative to increase not only the yields (Figures 3 and 4) but also the contents 
of lycopene, phenols, flavonoids and vitamin C, which are biomolecules with great importance for human health [71].

Author Contributions: Conceptualization, P.P.-R., E.O.R.-P. and M.F.-H.; methodology, M.F.-H., J.A.O.-V. and A.A.-S.; software, P.P.-R. and M.F.-H.; validation, P.Y.-C., M.F.-H. and P.P.-R.; formal analysis, P.P.-R., E.O.R.-P. and M.F.-H.; investigation, E.O.R.-P., A.A.-S., J.A.O.-V. and P.Y.-C., resources, P.P.-R., E.O.R.-P. and M.F.-H.; data curation and analysis, P.P.-R., E.O.R.-P. and M.F.-H.; writing-original draft preparation, E.O.R.-P., P.P.-R., A.A.-S. and M.F.-H.; writing-review and editing, E.O.R.-P.; visualization, E.O.R.-P.; supervision, E.O.R.-P., A.A.-S. and P.Y.-C., project administration, M.F.-H.; funding acquisition, A.A.-S., M.F.-H. and J.A.O.-V. All authors have read and agreed to the published version of the manuscript.

Funding: This research was supported by the National Council of Science and Technology of México (CONACYT) - postgraduate grant number to CVU 560948.

Acknowledgments: Alfonso Andrade-Sifuentes acknowledges the financial support given by the National Council for Science and Technology of Mexico (CONACYT) for graduate study. Thanks to the National Technological Institute of Mexico-Campus Instituto Tecnológico de Torreón, for the facilities granted. The authors are grateful for the technical assistance of the Water and Soil Analysis Laboratory technicians of FAZ_UJED, and the lab technicians of CIAD (Delicias, Chihuahua).

Conflicts of Interest: The authors declare no conflict of interest of any kind; the funders had no role in the design and implementation of this research and its data interpretation, nor in the decision to write and submit this manuscript.

\section{References}

1. Martínez-Damián, M.T.; Cano-Hernández, R.; Moreno-Pérez, E.C.; Sánchez-del Castillo, F.; Cruz-Álvarez, O. Effect of preharvest growth bioregulators on physicochemical quality of saladette tomato. Rev. Chapingo Ser. Hortic. 2019, 25, 29-43. [CrossRef]

2. Wakchaure, G.C.; Minhas, P.S.; Kamlesh, K.M.; Satis, K.; Jagadish, R. Effect of plant growth regulators and deficit irrigation on canopy traits, yield, water productivity and fruit quality of eggplant (Solanum melongena L.) grown in the water scarce environment. J. Environ. Manag. 2020, 11, 110320. [CrossRef] [PubMed]

3. SAGARPA. Secretaría de Agricultura, Ganadería, Desarrollo Rural, Pesca y Alimentación. Delegación Comarca Lagunera. 2019. Available online: http://www.sagarpa.gob.mx/dlg/laguna/informacion.htm. (accessed on 19 June 2020).

4. Acevedo-Peralta, A.I.; Leos-Rodríguez, J.A.; Figueroa-Viramontes, U.; Romo Lozano, J.L. Política ambiental: Uso y manejo del estiércol en la Comarca Lagunera. Multidiscip. Sci. J. 2018, 27, 3-12. [CrossRef]

5. CONAGUA. Comisión Nacional del Agua. Actualización de la Disponibilidadad Media Annual de Agua en el Acuifero Principal—Region Lagunera (0523). 2015. Available online: https://sigagis.conagua.gob.mx/gas1/ Edos_Acuiferos_18/coahuila/DR_0523.pdf (accessed on 11 July 2020).

6. SIAP. Servicio de Información Agroalimentaria y Pesquera. 2019. Available online: http//nube.siap.gob.mx/ cierreagr\{í\}cola (accessed on 11 July 2020).

7. Galindo, O.G.; Viramontes, U.F.; Cueto-Wong, J.A.; Núñez-Hernández, G.; Gallegos-Robles, M.A.; López-Martínez, J.D. Disponibilidad de nitrógeno usando dos tipos de estiércol de bovino lechero en cultivos de maíz forrajero y triticale. Nova Sci. 2019, 22, 124-141. [CrossRef]

8. Ali, Q. Organic Manuring for Agronomic Crops. In Agronomic Crops; Hasanuzzaman, M., Ed.; Springer: Singapore, 2019. [CrossRef]

9. Amir, K.; Fouzia, I. Chemical nutrient analysis of different composts (Vermicompost and Pitcompost) and their effect on the growth of a vegetative crop Pisum sativum. Asian J. Plant Sci. Res. 2011, 1, 116-130.

10. Vázquez, V.; García, H.; Salazar, S.; López, M.; Valdez, C.; Orona, C.; Preciado, R. Aplicación de estiércol solarizado al suelo y la producción de chile jalapeño (Capsicum annuum L.). Chapingo Ser. Hortic. 2011, 17, 69-74.

11. Lopez, M.J.D.; Salazar, S.E.; Trejo-Escareño, H.I.; García, H.J.L.; Navarro, M.M.; Vázquez-Vázquez, C. Produccion de algodón con altas densidades de siembra usando fertilizantes organicos. Phyton Rev. Inter. Bot. 2014, 83, 237-242.

12. Raffi, M.M.; Charyulu, P.B.B.N. Azospirillum-biofertilizer for sustainable cereal crop production: Current status. Recent Dev. Appl. Microbiol. Biochem. 2020, 193-209. [CrossRef] 
13. Niño Paul, M.B.; Pompe, C.S.C.; Edna, A.A.; Rodrigo, B.B.; Stephan, M.H. Evaluation of Biofertilizers in Irrigated Rice: Effects on Grain Yield at Different Fertilizer Rates. Agriculture 2012, 2, 73-86. [CrossRef]

14. Bona, E.; Lingua, G.; Todeschini, V. Effect of Bioinoculants on the Quality of Crops. In Bioformulations: For Sustainable Agriculture; Arora, N., Mehnaz, S., Balestrini, R., Eds.; Springer: New Delhi, India, 2016; pp. 93-124. [CrossRef]

15. Sangoquiza, C.A.; Viera, Y.; Yánez Guzmán, C.F. Biological Response of Azospirillum spp. to Different Types of Stress. Revista Centro Agrícola Universidad Central “Marta Abreu” de las Villas. 2018. Available online: http://cagricola.uclv.edu.cu (accessed on 3 October 2020).

16. Florez-Márquez, J.F.; Leal-Medina, G.I.; Ardila-Leal, L.D.; Cárdenas-Caro, D.M. Isolation and Characterization of Chizobacteria Associated with rice Crops (Oryza sativa L.) in norte de santander (Colombia). Agrociencia 2017, 51, 4 .

17. Salazar-Sosa, E.; Fortis-Hernández, M.; López-Martínez, J.D.; Muños-Alvarado, C.L.; Lara-Macías, M.E.; Amado-Álvarez, J.P.; Vázquez-Vázquez, C.; Trejo-Escareño, H.I.; Chavarría-Galicia, J.A. Comparison among solarization kind of pailes and their impact in the control of Cryptosporidium parvum and Giardia lamblia. Int. Res. J. Agric. Sci. Soil Sci. 2011, 1, 355-364.

18. SMART. La Fertilización del Cultivo de Tomate. 2020. Available online: https://www.smartfertilizer.com/es/ articles/tomato-fertilizer/ (accessed on 10 January 2020).

19. Lin, T.F.; Huang, H.I.; Shen, F.T.; Young, C.C. The protons of gluconic acid are the major factor responsible for the dissolution of tricalcium phosphate by Burkholderia cepacia CC Al74. Bioresour. Technol. 2006, 97, 957-960. [CrossRef] [PubMed]

20. Maeso, D.; Walasek, W. Evaluación de métodos para desinfectar semillas de tomate contra cancro bacteriano (Clavibacter michiganensis subsp. michiganensis). Agrociencia Urug. 2011, 16, 134-141.

21. Briones-Domínguez, E.J.; Velázquez-López, A.A.; Gómez-Cruz, L.A.; Vela-Gutiérrez, G. Viabilidad de bacterias ácido lácticas encapsuladas en un embutido de Pleorotus ostreatus Viability of encapsulated lactic acid bacteria in a Pleorotus ostreatus sausage. Rev. Int. Investig. Innov. Tecnol. 2020, 8, 47.

22. Mesfin Bogale, A.B.; DiGennaro. Nematode Identification Techniques and Recent Advances. Plants 2020, 9, 1260. [CrossRef]

23. Jalili, B.; Bagheri, H.; Azadi, S.; Soltani, J. Identification and salt tolerance evaluation of endophyte fungi isolates from halophyte plants. Int. J. Environ. Sci. Technol. 2020. [CrossRef]

24. Coromoto-Alcedo, Y.; Reyes, I. Microorganismos Promotores de Crecimiento en el Biocontrol de alternaria alternata en tomate (Solanum Lycopersicum L.). Bioagro 2018, 30, 59-66.

25. Ochoa-Jiménez, V.A.; Berumen-Varela, G.; Rivera-Domínguez, M.; Báez-Sañudo, B.; Troncoso-Rojas, R.; Tiznado-Hernandez, M.E. Development of a regeneration and genetic transformation protocol for tomato (Solanum lycopersicum L.) cv. Rutgers. Agrociencia Cienc. 2019, 53, 725-740.

26. López-Corona, B.E.; Mondaca-Fernández, P.; Gortáres-Moroyoqui, M.M.; Meza-Montenegro, J.; Balderas-Cortés, J.; Ruíz-Alvarado, C.; Rueda-Puente, E.O. Ecophysiology and biochemistry of salicornia bigelovii (Torr.) by effect of chitosanaib effect under Sonora desert conditions. Polibotánica 2020, 49, 75-92. [CrossRef]

27. Parra-Terraza, S.; Lara-Murrieta, P.; Villarreal-Romero, V.; Hernández-Verdugo, V. Crecimiento de plantas y rendimiento de tomate en diversas relaciones Nitrato/Amonio y concentraciones de bicarbonato. Fitotec. Mex. 2012, 35, 143-153. [CrossRef]

28. Liang, Y.; Urano, D.; Liao, K.L.; Hedrick, T.L.; Gao, Y.; Jones, A.M. A nondestructive method to estimate the chlorophyll content of Arabidopsis seedlings. Plant Methods 2017, 13, 26. [CrossRef] [PubMed]

29. Yu, X.; Zhao, P.; He, C.; Li, C.; Zhou, J.; Huang, Z. Isolation of a novel strain of Monoraphidium sp. and characterization of its potential application as biodiesel feedstock. Bioresour. Technol. 2012, 121, 256-262. [CrossRef] [PubMed]

30. Esparza-Rivera, J.R.; Stone, M.B.; Stushnoff, C.; Pilon-Smith, E.; Kendall, P.A. Effects of Ascorbic acid applied by two hydrocooling methods on physical and chemical properties of green leaf lettuce stored at $5{ }^{\circ} \mathrm{C}$. J. Food Sci. 2006, 71, 270-276. [CrossRef]

31. Hernández-Hernández, H.; Quiterio-Gutiérrez, T.; Cadenas-Pliego, G.; Ortega-Ortiz, H.; Hernández-Fuentes, A.D.; Cabrera de la Fuente, M.; Valdés-Reyna, J.; Juárez-Maldonado, A. Impact of selenium and copper nanoparticles on yield, antioxidant system, and fruit quality of tomato plants. Plants 2019, 8, 355. [CrossRef] 
32. Gutiérrez-Tlahque, J.; Santiago-Sáenz, Y.O.; Hernández-Fuentes, A.D.; Pinedo-Espinoza, J.M.; LópezBuenabad, G.; López Palestina, C.U. Influencia de los métodos de cocción sobre la actividad antioxidante y compuestos bioactivos de tomate (Solanum lycopersicum L.). Nova Sci. 2019, 11, 53-68.

33. Fernandez, C.; Pitre, A.; Llobregat, M.J.; Rondon, Y. Evaluacion del contenido de licopeno en pastas de tomate comerciales. [Determination of the Lycopene Content in Different Commercial Tomato Pastes]. Inf. Tecnol. 2007, 18, 31-38. [CrossRef]

34. Tortora, M.L.; Vera, L.; Naval, N.G.; Dantur, K.; Núñez, M.D.A.; Alderete, M.; Romero, E.R. Aislamiento, caracterización y actividad de cepas de Azospirillum brasilense asociadas a la caña de azúcar. Cultiv. Trop. 2019, 40, a07-e07.

35. Ocegueda-Reyes, M.D.; Casas-Solís, J.; Virgen-Calleros, G.; González-Eguiarte, D.R.; López-Alcocer, E. Isolation, identification and characterization of antagonistic rhizobacteria to Sclerotium Cepivorum. Mex. J. Phytopathol. 2019, 38, 146-159. [CrossRef]

36. SAS (Statistical Analysis System). SAS/STAT 9.4 User's Guide; SAS: Cary, NC, USA, 2016. Available online: https: //support.sas.com/documentation/cdl/en/statugintroduction/61750/PDF/default/statugintroduction.pdf (accessed on 3 October 2020).

37. Platel, K. Functional foods in Indian tradition and their significance for health. In Nutritional and Health Aspects of Food in South Asian Countries; Academic Press: Cambridge, MA, USA, 2020; pp. 87-98.

38. Ayed, L.; Mhir, S.; Hamdi, M. Microbiological, Biochemical, and Functional Aspects of Fermented Vegetable and Fruit Beverages. J. Chem. 2020. [CrossRef]

39. Chauhan, M.; Garg, V.; Zia, G.; Dutt, R. Potential Role of Phytochemicals of Fruits and Vegetables in Human Diet. Res. J. Pharm. Technol. 2020, 13, 1587-1591. [CrossRef]

40. FIT. Foreign and International Trade, Dedicated to the Promotion of Customs, Incoterms, Export and Import Articles. 2020. Available online: https://www.comercioyaduanas.com.mx/comercioexterior/tomate-exicano/ (accessed on 20 May 2020).

41. Galindo, F.S.; Teixeira Filho, M.C.M.; Buzetti, S.; Santini, J.M.K.; Alves, C.J.; Nogueira, L.M.; Ludkiewicz, M.G.Z.; Andreotti, M.; Bellotte, J.L.M. Corn Yield and Foliar Diagnosis Affected by Nitrogen Fertilization and Inoculation with Azospirillum Brasilense. Rev. Bras. Ciênc. Solo 2016, 40, 1-18. [CrossRef]

42. Coniglio, A.; Mora, V.; Puente, M.; Cassán, F. Azospirillum as Biofertilizer for Sustainable Agriculture: Azospirillum brasilense AZ39 as a Model of PGPR and Field Traceability; Springer Nature: Cham, Switzerland, 2019; Chapter 4. [CrossRef]

43. Domingues-Duarte, C.F.; Cecato, U.; Biserra, T.T.; Mamédio, D.; Galbeiro, S. Azospirillum spp. in grasses and forages. Rev. Mex. Cienc. Pecu. 2020, 11, 223-240. [CrossRef]

44. Domenico, P. Effect of Azospirillum brasilense on garlic (Allium sativum L.) cultivation. World J. Adv. Res. Rev. 2019, 2, 008-013. [CrossRef]

45. Araújo, E.O.; Martins, M.R.; Vitorino, A.C.T.; Mercante, F.M.; Urquiaga, S.S. Effect of nitrogen fertilization associated with diazotrophic bacteria inoculation on nitrogen use efficiency and its biological fixation by corn determined using 15 N. Afr. J. Microbiol. Res. 2015, 9, 643-650.

46. Beltrán-Peña, E.M.; Ayala-Rodríguez, J.A.; Bucio, J.L. Interrelaciones entre la disponibilidad de fosfato y el ambiente biótico del suelo en el crecimiento y desarrollo de las plantas. Cienc. Nicolaita 2020, 78, 59-74.

47. Moreno-Reséndez, A.; García-Mendoza, V.; Reyes-Carrillo, J.L.; Vásquez-Arroyo, J.; Cano-Ríos, P. Rizobacterias promotoras del crecimiento vegetal: Una alternativa de biofertilización para la agricultura sustentable. Rev. Colomb. Biotecnol. 2018, 20, 68-83. [CrossRef]

48. García-Rojas, D.E.; Vázquez-Vázquez, P.; Pérez-Corral, D.A.; Ruiz-Cisneros, M.F.; Berlanga-Reyes, D.I.; Ornelas-Paz, J.D.J.; Acosta-Muñiz, C.H.; Rios-Velasco, C.; Salas-Marina, M.A.; Osorio-Hernández, E. Streptomyces como biocontroladores in vitro de Exserohilum rostratum y productores de sustancias promotoras del crecimiento vegetal. J. Phytopathol. 2019, 37, 48-56. [CrossRef]

49. Licea-Herrera, J.I.; Quiroz-Velásquez, J.D.; Hernández-Mendoza, J.L. Impact of Azospirillum Brasilense, a rhizobacterium stimulating the production of indole-3-acetic acid as the mechanism of improving plants' grow in agricultural crops. Rev. Boliviana Quim. 2020, 37, 34-39. [CrossRef]

50. Sánchez, D.B.; Pérez, J.V. Caracterización y evaluación de PGPRs sobre el crecimiento de plántulas de Dioscorea rotundata in vitro. Agron. Costarric. 2018, 42, 75-91. [CrossRef]

51. Robson, R.L.; Jones, R.; Robson, M.R.; Schwartz, A.; Richardson, T.H. Azotobacter genomes: The genome of Azotobacter chroococcum NCIMB 8003 (ATCC 4412). PLoS ONE 2015, 10, e0127997. [CrossRef] 
52. Doncel, A.; Chamorro, L.; Pérez, A. Actividad in vitro de bacterias endófitas promotoras de crecimiento asociadas con pasto colosoana en el municipio de Corozal, Sucre. Rev. Colomb. Cienc. Anim. 2016, 8, 351-360. [CrossRef]

53. Baars, O.; Zhang, X.; Gibson, M.I.; Stone, A.T.; Morel, F.M.; Seyedsayamdost, M.R. Seyedsayamdost. Crochelins: Siderophores with an unprecedented iron-chelating moiety from the nitrogen-fixing bacterium Azotobacter chroococcum. Angew. Chem. Int. Ed. Engl. 2018, 57, 536-541. [CrossRef] [PubMed]

54. Benimeli, M.F.; Plasencia, A.; Corbella, R.D.; Guevara, D.A.; Sanzano, A.; Sosa, F.A.; de Ullivari, J.F. El Nitrógeno del Suelo; Cátedra de Edafología Facultad de Agronomía y Zootecnia Universidad Nacional de Tucumán: Tucumán, Argentina, 2019.

55. Steiner, F.; Queiroz, L.F.M.; Zuffo, A.M.; da Silva, K.C.; Lima, I.M.D.O. Respuesta de cacahuete a la co-inoculación de Bradyrhizobium spp. y Azospirillum brasilense y aplicación de molibdeno en suelo arenoso del Cerrado brasileño. Rev. Agron. 2020. [CrossRef]

56. Kai, M.; Piechulla, B. Plant growth promotion due to rhizobacterial volatiles-An effect of $\mathrm{CO}_{2}$. FEBS Lett. 2009, 583, 3473-3477. [CrossRef]

57. Karlidag, H.; Esitken, A.; Yildirim, E.; Donmez, M.F.; Turan, M. Effects of plant growth promoting bacteria on yield, growth, leaf water content, membrane permeability, and ionic composition of strawberry under saline conditions. J. Plant Nutr. 2010, 34, 34-45. [CrossRef]

58. Maidana, E.; Melgarejo, A.M.; Amarilla, D.; Ocampos, L.V.; Colman, P.; Mendoza, M.; Bogado, M.; Franco, R.; Silvero, O. Agronomic characteristics of corn inoculated with different doses of Azospirillum Brasiliense. Rev. Soc. Cient. Parag. 2020, 25, 49-57. [CrossRef]

59. Zambrano-Gavilanes, F.; Souza-Andrade, D.; Zucareli, C.; Sarkis-Yunes, J.; Amaral, H.; Matias da Costa, R.; Raia, D.; García, M.; de Fátima Guimarães, M. Efecto de la inoculación con cianobacterias y coinoculación con Azospirillum Brasilense sobre características fitométricas en maíz. Bioagro 2019, 31, 193-202.

60. González, F.; Fuentes, M. Mechanism of action of five plant growth promoters microorganism. Rev. Cienc. Agrícolas 2017, 34, 17-31. [CrossRef]

61. Almeida Moreira, B.R.; Silva Viana, R.; Lopes Favato, V.; Monteiro de Figueiredo, P.A.; Manzani Lisboa, L.A.; Tadao Miasaki, C.; Chagas Magalhaes, A.; Bispo Ramos, S.; Almeida Viana, C.R.; Dias Rezende Trindade, V.; et al. Azospirillum brasilense puede mejorar impresionantemente el crecimiento y desarrollo de Urochloa brizantha bajo riego. Agricultura 2020, 10, 220.

62. Souza, R.D.; Ambrosini, A.; Passaglia, L.M. Plant growth-promoting bacteria as inoculants in agricultural soils. Genet. Mol. Biol. 2015, 38, 401-419. [CrossRef]

63. Dursun, A.; Ekinci, M.; Dönmez, M.F. Effects of foliar application of plant growth promoting bacterium on chemical contents, yield and growth of tomato (Lycopersicon esculentum L.) and cucumber (Cucumis sativus L.). Pak. J. Bot. 2010, 42, 3349-3356.

64. Ordookhani, K.; Moezi, A.; Khavazi, K.; Rejali, F. Effect of plant growth promoting rhizobacteria and mycorrhiza on tomato fruit quality. Acta Hort. 2013, 989, 91-96. [CrossRef]

65. González, R.G.; Espinosa, P.B.; Cano, R.P.; Moreno, R.A.; Leos, E.L.; Sánchez, G.H.; Sáens, M.J. Influencia de rizobacterias en la producción y calidad nutracéutica de tomate bajo condiciones de invernadero. Rev. Mex. Cienc. Agrícolas 2018, 9, 367-379.

66. Fukami, J.; de la Osa, C.; Ollero, F.J.; Megías, M.; Hungria, M. Co-inoculación de maíz con Azospirillum brasilense y Rhizobium tropici como estrategia para mitigar el estrés de salinidad. Biol. Func. Plantas 2018, 45, 328. [CrossRef]

67. Ruiz, L.G.A.; Qüesta, A.G.; Rodríguez, S.D.C. Efecto de luz UV-C sobre las propiedades antioxidantes y calidad sensorial de repollo minimamente procesado. Rev. Iberoam. Tecnol. Postcosecha 2010, 11, 101-118.

68. Díaz, F.A.; Ortiz, C.F.E.; Espinosa, E.M. Mycorrhizal symbiosis and growth of sorghum plants irrigated with saline water. Rev. Chapingo Ser. Zonas Áridas 2016, 15, 55-64.

69. Pirlak, L.; Köse, M. Effects of plant growth promoting rhizobacteria on yield and some fruit properties of strawberry. J. Plant Nutr. 2009, 32, 1173-1184. [CrossRef]

70. Adriano, A.M.D.L.; Jarquín, G.R.; Hernández, R.C.; Salvador, F.M.; Monreal, V.C.T. Biofertilización de café orgánico en etapa de vivero en Chiapas, México. Rev. Mex. Cienc. Agrícolas 2011, 2, 417-431. 
71. Waliszewski, K.N.; Blasco, G. Propiedades nutraceúticas del licopeno. Salud Públ. México 2010, 53, $254-265$. [CrossRef]

Publisher's Note: MDPI stays neutral with regard to jurisdictional claims in published maps and institutional affiliations.

(C) 2020 by the authors. Licensee MDPI, Basel, Switzerland. This article is an open access article distributed under the terms and conditions of the Creative Commons Attribution (CC BY) license (http://creativecommons.org/licenses/by/4.0/). 